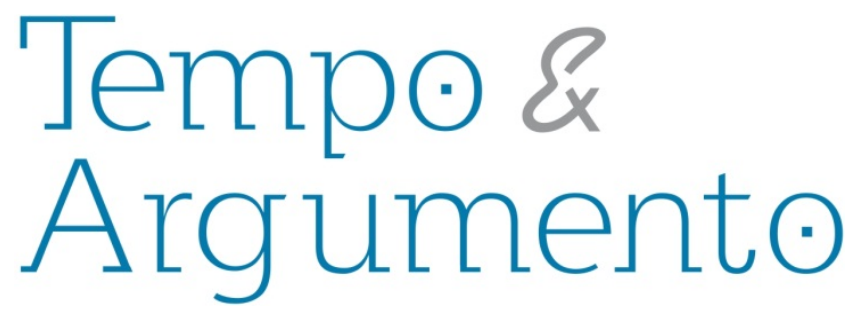

\title{
Ditadura militar brasileira: aproximações teóricas e historiográficas ${ }^{1}$
}

\begin{abstract}
Resumo
Como é comum na História do Tempo Presente, há um grande entrelaçamento entre política e pesquisa acadêmica no caso da história da ditadura militar brasileira. Consequentemente, é fundamental que a pesquisa arquivística seja conduzida por formulações teóricas bem assentadas. Este artigo discute o suposto revisionismo da historiografia sobre a ditadura militar brasileira; sustenta que o recrutamento de jovens simpatizantes para a luta armada gerou uma memória traumática; mostra o vício nominalista do debate sobre o caráter civilmilitar da ditadura; argumenta que a moldura institucional do estado de exceção ainda estava ativa em 1985 e demonstra que a saída da ditadura foi controlada pelos militares.
\end{abstract}

Palavras-chave: Ditadura Militar. Historiografia.

Revisionismo. Memória. Trauma.

\author{
Carlos Fico \\ Doutor em História pela Universidade de São \\ Paulo. Professor Titular da Universidade \\ Federal do Rio de Janeiro. Bolsista \\ produtividade em pesquisa do CNPq. \\ Brasil \\ carlos_fico@uol.com.br
}

\section{Para citar este artigo:}

FICO, Carlos. Ditadura militar brasileira: aproximações teóricas e historiográficas. Revista

Tempo e Argumento, Florianópolis, v. 9, n. 20, p. 05 - 74. jan./abr. 2017.

\section{DOI: $10.5965 / 2175180309202017005$}

http://dx.doi.org/10.5965/2175180309202017005

\footnotetext{
${ }^{1}$ As pesquisas do autor são feitas com o auxílio da bolsa de produtividade em pesquisa do CNPq.
} 


\title{
Brazilian military dictatorship: theoretical and historiographic approaches
}

\begin{abstract}
As is common in the History of Present, there is a significant interconnection between politics and academic research regarding the history of the Brazilian military dictatorship. Consequently, it is essential that archival research be guided by wellestablished theoretical formulations. This article discusses the alleged revisionism of the historiography on the Brazilian military dictatorship, argues that the recruitment of young leftwing students for the armed struggle has generated a traumatic memory, shows the weakness of the debate about the civil-military character of dictatorship, argues that the institutional framework of the state of exception was still active in 1985 and demonstrates that the project of "Abertura" was controlled by the military.
\end{abstract}

Keywords: Brazilian Military Dictatorship.

Historiography. Revisionism. Memory. Trauma.

“- Só trate de teoria depois dos sessenta anos!”. Eu tinha apenas 23, queria escrever sobre o conceito de mentalidades, mas meu professor de metodologia da História era muito sarcástico. Perguntei, fazendo-me de tolo: “Devo aguardar porque serei mais inteligente?”, ele respondeu “- Sim”, mas ressalvou: “também pode ocorrer que esteja esclerosando, mas isso será bom porque os amigos que você vai criticar vão ter pena e o perdoarão mais facilmente". Eu ainda não tenho sessenta anos.

O bom debate teórico e historiográfico depende da maturidade que advém de muitas leituras e do discernimento que nos permite identificar autores relevantes. Eles podem ser colegas próximos ou amigos quando se trata de tema que também praticamos, como é o caso aqui. No Brasil, a crítica teórica e historiográfica não é comum, sendo frequentes as resenhas aprobativas e as críticas indiretas que se valem do 
pronome indefinido "certo" (“certa historiografia”, “certos autores”). Citar criticamente um autor parece antiético. Ora, penso o contrário: um especialista em nosso tema, que analise detidamente e critique nossa obra - sem que a favoreça por amizade ou a persiga por qualquer divergência -, que mais poderá desejar quem valoriza o debate acadêmico?

Arvorar-se em especialista capaz de avaliar outrem soa presunçoso. Alego que tenho pesquisado os temas da ditadura militar, da historiografia brasileira e da teoria e metodologia da história nos últimos trinta anos.

Este artigo pretende identificar algumas das mais relevantes obras sobre a ditadura militar, recentes ou não, para discutir as seguintes questões teórico-conceituais e historiográficas que têm vindo à tona ultimamente: 1) a acusação de revisionismo feita por historiadores marxistas a pesquisadores que 1.1) tacham João Goulart de golpista, 1.2) questionam o caráter democrático da esquerda nos anos 1960, 1.3) lançam mão do conceito de cultura política e 1.4) não utilizam o conceito de classe social; 2) os problemas contidos na crítica originalmente feita por Daniel Aarão Reis Filho à memória confortável sobre a "luta armada"; 3) a importância da noção de retroalimentação entre "luta armada" e repressão para se compreender a diferença existente entre a inserção dos quadros organizados e dos simpatizantes nas ações armadas; 4) o debate sobre a denominação e a periodização do golpe e do regime e 5) o meu entendimento sobre a saída da ditadura como projeto de longa duração e maturação pouco influenciado pelos setores de oposição ao regime.

Até os anos 1980, os debates teóricos sobre os regimes militares latinoamericanos, inclusive o brasileiro, diziam respeito a modelos gerais de interpretação e se davam na Ciência Política. Carentes de diálogos com evidências empíricas, tais debates nunca chegaram a interessar os historiadores (FICO, 2004, p. 32). As informações disponíveis sobre a ditadura provinham da imprensa, de discursos oficiais e de depoimentos ou memórias: são recentes os trabalhos que têm acesso a grandes fundos documentais.

A escassez de fontes documentais não existe mais: o regime militar brasileiro preservou muitos acervos, vários deles abertos à consulta pública desde o final dos anos 
1980 - abundância que me sugeriu a expressão "ditadura documentada” (FICO, 2008a). Em consequência, avolumaram-se as descobertas empíricas e mudou o perfil da produção sobre o tema. Se o desafio anterior eram as fontes, passou a ser, então, a análise, o estabelecimento de novas interpretações e de hipóteses explicativas - etapa do conhecimento evidentemente mais difícil e que, por isso mesmo, tem suscitado alguns debates.

O mais ruidoso é a acusação de revisionismo que historiadores marxistas têm feito a pesquisadores como Argelina Figueiredo, Daniel Aarão Reis Filho, Jorge Ferreira e Denise Rollemberg. Em 2004, quando perguntado se promoveria algum congresso para marcar os 40 anos do golpe de 1964, sugeri que reuníssemos todas as instituições do Rio de Janeiro em um grande evento. A ideia foi acatada e o seminário atraiu o interesse do público e da imprensa. Foi nesse contexto que a "operação revisionista" se tornou “dominante no mainstream acadêmico brasileiro", como diria, dez anos depois, Demian Bezerra de Melo, um dos autores marxistas (MELO, 2014, p. 161).

\section{1) Revisionismo}

\section{1) Golpismo de Goulart}

Em 2004, Caio Navarro de Toledo, precursor dos estudos sobre o golpe de 1964, chamou atenção para a fragilidade da acusação de golpismo contra Goulart. Contrapondo-se aos autores que assim teriam caracterizado o ex-presidente, Toledo os acusou de revisionistas - grave pecha que tanto Caio quanto Demian usam com malograda cautela. ${ }^{2}$ Diz corretamente Toledo que não há documentos reveladores de “planos golpistas ou continuístas de Goulart”, não se devendo confundir golpismo com esquerdismo, acusação que se poderia fazer a setores da esquerda (ou seja, inclusive a Goulart e a Brizola) por suas "palavras estridentes e discursos eloquentes” (TOLEDO, 2004, p. 37, 48 e 44).

\footnotetext{
${ }^{2}$ Algumas acusações são irrefletidas, como a feita por Virgínia Fontes, segundo a qual os revisionistas procuram redimir as ditaduras (FONTES, 2014, p. 9). Demian Melo também concede ao aborrecido acusatório marxista com as invectivas "releitura reacionária" e "historiografia apologética". Ver Melo (2014, p. 48).
} 
O debate sobre o suposto caráter golpista de João Goulart é interessante porque há dois momentos em que o então presidente lançou mão de mecanismos fortes de pressão, assustando a todos e dando margem a especulações sobre eventuais planos inconstitucionais que pudesse ter. Foi bem-sucedido em uma ocasião e fracassou na outra. Refiro-me, naturalmente, aos episódios da antecipação do plebiscito sobre o parlamentarismo e à solicitação do Estado de Sítio. São fatos conhecidos e não é necessário descrevê-los, bastando chamar atenção para o que terá havido, eventualmente, de golpismo da parte de Goulart. Cabe destacar, inicialmente, que o objetivo, nos dois casos, era levar o Congresso Nacional a votar com o governo, de modo que poderíamos talvez falar em pressões indevidas, não em golpismo.

Quem melhor capturou essas atitudes que poderiam indicar uma espécie de prenúncio de golpe foi Marco Antonio Villa, historiador que também é acusado de revisionista, além de não contar com nenhuma simpatia da esquerda e da academia por conta das críticas cáusticas que faz a ambas, como polemista e panfletário, em rádio, TV e jornais. Como historiador, Villa é capaz de controlar grande massa de informações, usando muito as biografias e a imprensa, valendo-se de memória privilegiada, com a qual recheia de fatos saborosos a narrativa cronológica e algo linear que usa construir, dandoIhe cor e interesse. Villa destaca que Goulart pressionou o Congresso Nacional em 1962, tendo em vista a antecipação do plebiscito, por meio de nota do comandante do III Exército na qual o general Jair Dantas Ribeiro dizia que a intransigente oposição dos políticos mais apaixonados poderia "acarretar consequências imprevisíveis para o destino das instituições". Dantas Ribeiro, em telegrama ao ministro da Guerra, disse que seu alerta não era ameaça ou imposição, mas advertência. O general obteve o apoio do comandante do I Exército, Osvino Alves, como registra Villa, que também anota a greve geral do Comando Geral do Trabalhadores (CGT) e a renúncia do gabinete Brochado da Rocha na véspera da votação da proposta de antecipação. Essa pressão pela antecipação do plebiscito foi classificada por Carlos Lacerda como golpe que o governo vinha articulando, sobretudo por meio do "gabinete negro", secreto, formado pelos assessores de Jango identificados por Lacerda como comunistas (Raul Ryff, Alvaro Vieira Pinto, Cibilis Viana e outros). O Correio da Manhã condenou Dantas Ribeiro no dia 15 de 
setembro de 1962 por dizer-se incapaz de conter os "ânimos populares" caso a antecipação do plebiscito não fosse aprovada e chamou sua declaração de "nota subversiva". Realmente, falava-se na imprensa que Jango pretendia, no mínimo, o “presidencialismo absolutista” e que sua jogada final viria quando fosse votado o plebiscito. ${ }^{3}$ Enfim, havia muito jogo político, ameaças, previsões falhas, mas resta por demonstrar a existência de atmosfera de efetiva coerção sob a qual o Congresso teria aprovado a antecipação do plebiscito (VILLA, 2004, p. 82-84). Ou seja, o Congresso poderia ter votado contra a antecipação, mas é certo que Goulart jogou pesado.

A tentativa de Goulart de decretar o Estado de Sítio também é frágil como indicação de golpismo. De fato, como diz Villa, no dia em que encaminhou a mensagem ao Congresso Nacional houve deslocamento de tanques para o Ministério da Guerra, mas isso pode ser justificado de muitas maneiras. Marco Antonio afirma que, com o Estado de Sítio, Goulart poderia intervir nos estados e planejava fazê-lo em São Paulo, Rio de Janeiro e Pernambuco (VILLA, 2004, p. 119). O problema é que o Estado de Sítio não permitia explicitamente a intervenção em estados e Villa não apresenta evidências sobre planos de intervenção nesses estados, ou melhor, apresenta provas insuficientes ou questionáveis, como um depoimento de José Serra de 1980 e uma entrevista sua de 1994. Em 1980, Serra - que era presidente da UNE em 1963 - garantiu que interventores seriam nomeados em todos os estados. Na entrevista de 1994, Serra disse que o Estado de Sítio foi apresentado como golpe em reunião da qual participou. Mas, no livro de memórias que publicou em 2014, Serra relativizou muitíssimo tais afirmações: revelou que Jango lhe confidenciou, em outubro de 1963, que sabia que não terminaria seu mandato, que os possíveis desdobramentos golpistas eram cogitados na verdade por Brizola, que a intervenção em Pernambuco era apenas uma suspeita que tinha, que Jango não era um golpista inveterado e que não acredita que Goulart "tivesse atuado de forma entusiasmada na confecção do roteiro que ia do estado de sítio ao regime de exceção" (SERRA, 2014, p. 19). Há também velho caso mal contado sobre um tenente-coronel que teria sido designado para prender Carlos Lacerda. A movimentação de tropas mais suspeita nesse dia ocorreu no Palácio das Princesas, em Recife. Em livro mais recente,

\footnotetext{
${ }^{3}$ Correio da Manhã. Rio de Janeiro, 19 de setembro de $1962.1^{\circ}$ Caderno, p. 6.
} 
Villa reitera a acusação de golpismo e a amplia, garantindo que Goulart "sonhava com a reeleição", também sem apresentar evidências empíricas (VILLA, 2014, p. 27).

Um aspecto interessante não é mencionado pela literatura especializada: se Jango era tão claramente golpista, por que a oposição não buscou o caminho legal do impeachment? O deputado pela União Democrática Nacional (UDN) da Guanabara, Aliomar Baleeiro, bem que tentou, por meio de articulações com o Partido Social Democrático (PSD): se Jango fosse afastado a partir de agosto de 1963, o Congresso elegeria seu substituto, sendo grandes as chances de o maior partido conquistar a Presidência da República. A tese não prosperou e a direita se provou golpista.

\section{2) Esquerda não democrática}

Em relação aos historiadores que afirmam que as esquerdas não eram democráticas, Caio Navarro de Toledo, de modo muito oportuno, destacou que as reformas de base propunham a "ampliação da democracia liberal excludente" (TOLEDO, 2004, p. 48, nota 38). A questão de quem era adepto da democracia é simples. De fato, Argelina Cheibub Figueiredo, em sua tese de doutoramento em Ciência Política apresentada à Universidade de Chicago em 1987, afirmou que "os grupos esquerdistas e pró-reformas buscavam essas reformas ainda que ao custo da democracia (...) propunham e estavam dispostos a apoiar soluções não democráticas. Aceitavam o jogo democrático somente enquanto fosse compatível com a reforma radical" (FIGUEIREDO, 1993, p. 202). São afirmações anacrônicas que decorrem talvez do fato de que a autora graduou-se em Ciências Sociais e fez seu mestrado em Ciência Política: sua tese carece de perspectiva histórica e não apresenta embasamento teórico sofisticado, como já sugeri em outro trabalho (FICO, 2004, p. 50). Suas conclusões indicam que Goulart não soube fazer escolhas adequadas, de modo que as oportunidades de implementação das reformas sob regras democráticas teriam se reduzido. Naturalmente, vê-se nessas conclusões o influxo intelectual de Adam Przeworski, orientador de Argelina, fomentador da teoria das escolhas disponíveis aos agentes. O anacronismo consiste em cobrar daqueles que viveram os anos 1960 adesão a valores democráticos que seriam comuns algumas décadas depois. Jorge Ferreira concordou com a posição de Argelina e por isso 
também foi criticado pelos marxistas (FERREIRA, 2003, p. 400; FERREIRA, 2009, p. 188). Denise Rollemberg evitou o anacronismo quando afirmou que as esquerdas, "como de resto a sociedade (... ) não tinham a democracia como um valor supremo", e salientou, corretamente, que "a construção da memória deste passado tem sido feita menos à luz dos valores que nortearam as lutas de então e mais em função do presente, dos anos 1980, quando a referência era a democracia - e não mais a revolução" (ROLLEMBERG, 2003, p. 47-48). A última afirmação, entretanto, é algo supérflua, pois, toda construção de memória obedece a esse influxo. Ora, o historiador, se quiser, pode enveredar pelo terreno das disputas de memórias, das apropriações que a sociedade faz do passado por sua conta e risco, mas o uso propriamente dito do passado, a memória que afinal prevalece - sobre tais coisas é certo que não temos controle acadêmico, restando-nos atuar como cidadãos.

Os críticos do chamado revisionismo atribuem importância desmedida ao trabalho de Argelina Figueiredo. Demian Melo diz que a tese da cientista política deve ser considerada "um marco na literatura revisionista sobre o golpe" (MELO, 2006, p. 121. Grifado no original) até porque ela se contraporia a René Armand Dreifuss (cuja tese, de 1980, seria publicada em 1981 com o título 1964: a conquista do Estado) - e os historiadores marxistas valorizam bastante o trabalho de Dreifuss. Aliás, assim como a tese de Argelina, a de Dreifuss - cujas qualidades todos reconhecemos - também é supervalorizada pelos críticos marxistas apesar de suas fragilidades. ${ }^{4}$ No caso da tese de Argelina, além da mencionada ausência (do meu ponto de vista) de perspectiva histórica, creio, ademais, que há alguma singeleza na suposição de que a esquerda radicalizada de Leonel Brizola pudesse simplesmente considerar racionalmente, como escolha possível, não se comportar como o que de fato era: esquerdista e radicalizada. O mesmo pode ser dito de Jango, isto é, não se pode desconsiderar toda a conjuntura histórico-política e a trajetória de Goulart e simplesmente supor que ele tivesse uma cesta de alternativas que pudesse escolher: muitos "constrangimentos" - para mencionar o enfoque de Adam Przeworski - teriam de ser considerados.

\footnotetext{
${ }^{4}$ Creio que o principal problema da tese de Dreifuss é que ela não distingue entre a campanha de desestabilização patrocinada contra Goulart e a conspiração por sua derrubada, coisas completamente diferentes. Já fiz essa crítica e pesquisei a distinção em diversos trabalhos anteriores.
} 
Na verdade, a tese de Argelina - além de sua hipótese empírica já mencionada -, mais do que se contrapor a Dreifuss, pretendeu criticar os trabalhos anteriores que buscaram qualquer tipo de determinação estrutural para explicar o golpe de 1964. Por essa razão, além de tentar confrontar autores que supunham a inevitabilidade do golpe em função de fatores econômicos, Argelina criticou também a determinação dos fatores institucionais - presente na tese de Wanderley Guilherme dos Santos. A tese de Santos vinha sendo preparada e divulgada desde 1969, sendo talvez esse o interlocutor mais importante de Argelina, já que Wanderley e Argelina encontravam-se, por assim dizer, no mesmo escopo intertextual da Ciência Política norte-americana com suas questões sobre impasses institucionais, escolhas etc. O trabalho de Wanderley propõe a famosa tese sobre paralisia decisória fundada no modelo teórico da "competição política e cálculo do conflito". Também de inspiração antimarxista, Santos tenta explicar em termos institucionais o que ele chama de colapso do sistema político em 1964. Não vou retomar esse antigo debate, ${ }^{5}$ mas apenas situar que os críticos dos chamados revisionistas deveriam enfrentar o efetivo oponente - e sua inextricável construção teórica - e não o castelo de cartas que tomaram como fortaleza.

Há aspecto curioso a destacar: tanto Argelina Figueiredo quanto Wanderley Guilherme dos Santos dialogaram com o famoso cientista político Alfred Stepan. Argelina concorda com a afirmação de Stepan de que Goulart, no momento final de seu governo, radicalizou sua posição e perdeu qualquer possibilidade de apoio. Santos concorda com a ideia de fragmentação do apoio político de Stepan, mas diz que ela não decorria das coligações eleitorais, mas das coalizões parlamentares. O livro de Alfred Stepan (STEPAN, 1971) é conhecido por essas generalidades e, sobretudo, pela tese de que a singularidade da intervenção militar de 1964 estaria no abandono do padrão "moderador" que teria prevalecido até então, isto é: os militares brasileiros faziam breves intervenções, “arrumavam a casa" e a devolviam aos civis. Em 1964, segundo Stepan, foi diferente: eles vieram para ficar. Por que mudou o padrão moderador? Conforme ensinou o cientista político norte-americano, isso teria acontecido porque os militares teriam se sentido diretamente ameaçados pela possibilidade de Goulart dar um golpe, que Stepan

\footnotetext{
${ }^{5}$ Ver detalhes em Fico (2004, p. 44 e seguintes.)
} 
denominou eufemisticamente "dar uma solução à crise” (STEPAN, 1971, p. 143). Ele afirmou que Goulart "esperava mobilizar o poder político das massas e exigir as reformas através de um plebiscito ou de decreto, ou pressionando o Congresso, ou mesmo fechando-o" (STEPAN, 1971, p. 141). Isso teria levado à mudança do padrão "moderador”, de modo que os militares teriam optado por um governo militar autoritário duradouro. Fundamentados na Doutrina de Segurança Nacional - completa Stepan - os militares teriam se sentido capacitados para a empreitada (STEPAN, 1971, p. 137). Portanto, há de ter sido Stepan o primeiro a considerar, no espaço acadêmico, Goulart golpista.

As especulações de Alfred Stepan tornaram-se respeitadas e referendadas na academia. O livro é sua tese de doutoramento, apresentada à Universidade de Colúmbia em 1969 com o título Patterns of Civil-military Relations: the Brazilian Political System, mas foi publicada com o título The Military in Politics: Changing Patterns in Brazil. A data da defesa aqui é importante porque essa temática vinha sendo discutida pelo Departamento de Estado desde antes de 1964. De fato, como demonstrei em trabalho anterior, o embaixador norte-americano no Brasil conseguiu convencer o Departamento de Estado de que Goulart planejava um golpe. Em seus telegramas para Washingon, Lincoln Gordon sustentava a tese de que isso seria feito com o apoio dos comunistas que, finalmente, tomariam o controle de tudo (FICO, 2008, p. 90). O secretário de Estado, Dean Rusk, adotou, no dia 2 de abril de 1964, como versão governamental norte-americana, a suposta intenção de Goulart perpetuar-se no poder (FICO, 2008, p. 130).

Poucos dias depois do golpe, o conselheiro da seção da embaixada dos Estados Unidos em Brasília, Robert W. Dean, enviou um telegrama ao Departamento de Estado recomendando a leitura do ensaio que ele havia apresentado ao War College intitulado The Military in Politics in Brazil (título que, coincidentemente, é muito parecido com o do livro que Alfred Stepan publicaria anos depois). Robert Dean dizia nesse ensaio que "os militares têm desempenhado um papel estabilizador na vida política do Brasil. Como últimos fiadores da ordem pública e dos processos constitucionais, os militares exerceram uma influência moderadora". 6 Robert Dean conversou sobre o tema com

\footnotetext{
6 USA. National Archives. RG59 1969/1966. Box 1943. Airgram from Amembassy Brasilia Office to Department of State. April 4, 1964.
} 
Golbery do Couto e Silva em março de 1965, quando o general concordou com suas ideias afirmando que a permanência dos militares no poder por mais tempo era importante para evitar a necessidade de futura intervenção militar. ${ }^{7}$ Ainda em 1965, no mês de novembro, o marechal Castelo Branco recebeu o embaixador Lincoln Gordon para uma conversa na qual o embaixador norte-americano mencionou o papel dos militares como poder moderador:

Qualquer um familiarizado com a história brasileira saberia que o papel político histórico das Forças Armadas era o de intervir para colocar a nação no caminho da ordem e do progresso quando ela estava ameaçada de sair dos trilhos, exercendo mesmo o "poder moderador" contido na constituição imperial até 1889 , mas não para governar. Agora parecia haver alguma indicação de desejo pelas Forças Armadas para assumir a responsabilidade governamental em si. ${ }^{8}$

Não se sabe se Alfred Stepan se inspirou na interpretação do embaixador Lincoln Gordon, que Robert Dean trabalhou em sua monografia, sobre o "poder moderador" dos militares, mas a semelhança entre as perspectivas é grande. ${ }^{9}$ Seja como for, essas avaliações genéricas foram elevadas à condição de enunciados objetivos com pretensão de verdade, admitidas e referendadas pela academia, ainda que tenham frágil evidenciação empírica e origem não acadêmica - para não dizer suspeita. Sendo norteamericano, não é abusivo cogitar que Stepan tenha conversado com o embaixador e com o conselheiro. No dia 10 de abril de 1964, o embaixador sugeriu ao secretário de Estado, Dean Rusk, que plantasse notícias na imprensa ("additional unattributed background for press") sobre o golpismo de Goulart (FICO, 2008, p. 140): é bastante provável que Gordon tenha praticado no Brasil o que aconselhou ao seu chefe. Stepan estava no Brasil na época do golpe, ainda não era o conhecido cientista político que se tornaria e trabalhava como correspondente para a revista The Economist (STEPAN, 1971, p. 141). Ele publicou um artigo na revista no número de 4 de abril de 1964 intitulado Mend or End, no qual dizia

\footnotetext{
7 USA. National Archives. RG59 1964/1966. Box 1937. Memorandum of Conversation. Airgram March 16, 1965.

8 USA. National Archives. RG59 1964/1966. Box 1942. Airgram from Gordon to Department of State. November 3, 1965.

${ }^{9} \mathrm{O}$ trabalho de Dean chegou a ser mencionado por John J. Johnson (The Military and Society in Latin America. Stanford University Press, 1964), por Roberto Calvo (La doctrina militar de la seguridad nacional. Universidad Catolica Andres Bello, 1979) e por Schneider (1971, p. 119). Nunca consegui encontrá-lo, nem nas bibliotecas que o diplomata indica em seu telegrama de 1964.
} 
que Goulart pretendia emendar ou acabar com a Constituição e o Congresso, que sua mensagem ao Congresso continha elementos extra-legais, que o presidente poderia vir a governar por decreto e que a esquerda (e Goulart) pretendia adiar a eleição presidencial. Segundo Stepan, uma das principais reformas de base seria a eliminação da cláusula da inelegibilidade de Jango..$^{10}$ Ou seja, por coincidência ou por encomenda, ele fez o que Lincoln Gordon queria.

\section{3) Culturalismo}

As acusações de desamor à democracia e de golpismo de Goulart são questões empíricas. A última seria resolvida, por exemplo, se surgisse um plano de Jango para perpetuar-se no poder. A crítica que os historiadores marxistas fazem ao suposto revisionismo ganha relevo teórico quando aponta as fragilidades do conceito de cultura política, aspecto que é mais bem elaborado por Marcelo Badaró Mattos. Para ele, o predomínio do conceito de cultura política - corretamente identificado entre os autores acusados de revisionistas - estaria a indicar um determinismo de polo oposto ao economicismo marxista, a saber, o culturalismo (MATTOS, 2014, p. 70). Se é fácil verificar a ocorrência do predomínio mencionado, mais complexo é sustentar a hipótese do culturalismo. Assim como é muito difícil encontrar na historiografia algum autor que se encaixe na caricatura economicista descrita por críticos antimarxistas como Glaucio Ary Dillon Soares ou Wanderley Guilherme dos Santos, tampouco haverá historiadores que sustentem, sem mediações, que a esfera da cultura determina todas as demais instâncias da realidade. ${ }^{11}$ É bem verdade que, no momento de afirmação da Nouvelle Histoire (também uma tendência antimarxista), Roger Chartier fez afirmações irresolutas nesse sentido. ${ }^{12}$ Mas, entre os historiadores brasileiros em pauta, prevalecem abordagens equilibradas.

Parece-me que a crítica que se deve fazer ao conceito de cultura política precisa mirar sua fragilidade imanente e não o risco de os autores tornarem a esfera da cultura

\footnotetext{
${ }^{10}$ The Economist. London, Issue 6293, Apr. 4, 1964, p. 31.

${ }^{11}$ Para uma crítica aos excessos antimarxistas mencionados, queira ver Fico (2004).

${ }^{12}$ Refiro-me ao famoso artigo de 1989 no qual Chartier afirma que não há prática ou estrutura que não seja produzida pelas representações. Chartier (1989).
} 
determinante em termos monocausais. De fato, o uso que temos feito desse conceito é problemático. ${ }^{13}$ Muitos de nós o utilizamos sem qualquer problematização, referindo-o às considerações básicas de Serge Berstein, que também parte da crítica à insuficiência do marxismo - espécie de tributo teórico pago pela geração que viveu o predomínio acadêmico do marxismo - e se insere na tradição francesa de pragmatismo metodológico: ele busca respostas para o problema das motivações do político, algo que substitua as sondagens de opinião indisponíveis para os historiadores. As definições que Berstein apresenta para cultura política são amplas e serviriam também para mentalidades (políticas), representações (políticas), imaginário (político) ou outro conceito assemelhado que quiséssemos inventar (BERSTEIN, 2009, p. 31). Ele também não deixa claro se existe ou não uma cultura política global e, em alguns momentos, o conceito se aproxima da noção de mito e de utopia (BERSTEIN, 2009, p. 32-34).

No texto da conferência que não pôde apresentar no Brasil em 2008, mas que foi publicado logo depois, Berstein disse que "o ato político é em grande parte um fenômeno individual" e que a cultura política é "resultante do banho cultural em que o indivíduo está imerso" (BERSTEIN, 2009, p. 41). Ora, no início do século XXI, as questões teóricas referidas aos condicionamentos estruturais da ação individual e às reflexões sobre a crise da filosofia do sujeito - amplamente relacionadas com a crise da razão moderna - já compunham literatura internacional vastíssima e amplamente debatida. Assim, gera certa inquietação o enunciado tão singelo de Berstein sobre o caráter individual do ato político. Também causa confrangimento a afirmação de que a cultura política resulta do banho de imersão do indivíduo na cultura, tentativa de resolução por contiguidade do magno problema da relação entre sujeito e estrutura. As duas afirmações são - para dizer o mínimo - discutíveis e fragilizam a proposição feita pelo autor do conceito de cultura política na medida em que o embasam.

Em suas críticas, Marcelo Badaró associa o suposto determinismo cultural ao pósmodernismo, "caldo geral em que o culturalismo acaba encontrando, assumidamente ou não, seus nutrientes principais (...)" (MATTOS, 2014, p. 70). A observação é interessante e

\footnotetext{
${ }^{13}$ Estou entre os que fazem uso superficial do conceito, na medida em que ele "ajuda a pensar". Fiz isso, por exemplo, em Fico (2015, p. 107).
} 
modernismo, mas da crise das teorias sociais globais - marxismo à frente, com a crise da hipótese da determinação em última instância da base econômica - e do relativo esgotamento da história quantitativa ou serial (que foi a maneira pela qual tal crise foi percebida pela História predominante na França, sempre de modo teoricamente mitigado). Isso se deu em meados dos anos 1970: como se sabe, o "manifesto" da Nouvelle Histoire é de 1974 (refiro-me à coleção em três volumes Faire de l'histoire dirigida por Jacques Le Goff e Pierre Nora), anterior, portanto, ao livro fundador de Jean François Lyotard (La condition postmoderne), de 1979. Como se vê, a antropologização da história, inclusive da história política, é anterior à irrupção do pós-modernismo.

Esse ponto parece nos levar longe demais da discussão sobre a ditadura militar, mas, contando com a benevolência do leitor, espero mostrar sua pertinência. De fato, a chamada crise da História foi a manifestação, em nosso campo, da crise da razão moderna e da filosofia do sujeito. Ela se constituiu a partir de uma série de manifestações surgidas desde meados dos anos 1970, a saber: (a) a crítica da teoria literária às pretensões científicas da História feita por Hayden White e que levaria à chamada questão da narrativa; (b) a crítica da história macro-estrutural e quantitativa feita pelos novos historiadores dos Annales a seus predecessores; (c) a decorrente opção pela análise da subjetividade humana e pela esfera do cotidiano, que gerou especialidades como as histórias das mentalidades, do cotidiano, da vida privada, a micro-história e outras de algum modo influenciadas pela perspectiva antropológica e (d) a crise do marxismo como teoria social global, sobretudo tendo em vista as fragilidades das hipóteses da determinação da base econômica e da hierarquização e conflitividades sociais baseadas na estrutura de classes. São temas conhecidos e aqui os menciono apenas para destacar decorrência sobre a qual, ao contrário, não há a devida reflexão: o empirismo como fuga do desconforto teórico causado pela crise da História e as consequências disso. 
De fato, esse é um problema que, naturalmente, não afeta apenas a historiografia sobre a ditadura militar brasileira, mas também a afeta. É flagrante que, desde a crise da História (ela pode ser situada, aproximadamente, entre meados dos anos 1970 e metade final dos anos 1980), a usual resistência da maioria dos historiadores ao debate teórico se tornou efetivo desalento: o conforto teórico proporcionado pelo marxismo deixara de existir (convém reiterar: havia verdadeiro predomínio acadêmico do marxismo nos anos 1950-1970, inclusive de formas abrandadas da corrente, como a praticada pela segunda geração dos Annales). Com isso, muitos historiadores, aqui e alhures, a partir dos anos 1980, voltaram-se para os arquivos, para as evidências empíricas, como uma espécie de refúgio, evitando o debate teórico mais amplo e adotando, quando muito, conceitos ad hoc. Esses são os pontos que quero sublinhar: como consequência da crise teórica, experimentamos forte empirismo e significativa produção de conceitos aplicáveis a estudos históricos específicos. O empirismo leva a muitos problemas, sobre os quais, entretanto, há algum debate, especialmente relativo à crença sobre o acesso ao real por meio dos vestígios, à construção da narrativa histórica com pretensão de verdade porque fundamentada em documentos e assim por diante.

Entretanto, do ponto de vista dos diversos conceitos ad hoc - isto é, que não se articulam com teorias sociais globais haja vista sua decadência - temos refletido pouco. Em alguns casos, tais conceitos apenas formalizam comportamentos usuais, dando-lhes nome, menos do que conceptualizando-os. Tal procedimento lembra as pretensões de Hempel para estabelecer hipóteses universais baseadas em "regularidades gerais", muitas vezes referidas à psicologia individual ou social, e que são conhecidas, familiares e subentendidas (HEMPEL, 1942, p. 40). Seriam as leis implicitamente assumidas de Nagel (NAGEL, 1952, p. 163). Por exemplo, se eu disser que "as pessoas fizeram tudo o que foi possível para viver melhor", provavelmente todos concordarão comigo. Isso é uma lei histórica? Uma hipótese universal baseada em regularidades gerais? E se eu disser que, nas terríveis condições da escravidão moderna, apesar da brutal violência, os escravos tudo fizeram para viver um pouco melhor, ainda que isso tenha implicado alguma negociação com o senhor branco? Outro exemplo: se, por hipótese, durante a ditadura, alguém estivesse na iminência de ser preso e tivesse amigos poderosos, será que 
recorreria a eles em busca de proteção? A ideia de contratualismo aplicada à escravidão levou historiadores marxistas a acusar de revisionistas os que a defendiam - isso no início dos anos $1990 .{ }^{14}$ Rodrigo Patto Sá Motta supõe que o recurso a laços pessoais durante a ditadura militar para livrar-se da repressão foi "arranjo tradicional da cultura política" (MOTTA, 2014, p. 318).

Denise Rollemberg, além de usar extensivamente o conceito de cultura política, também lança mão da noção de zona cinzenta (metáfora de Primo Levi, em contexto narrativo específico, adotada por Pierre Laborie para analisar os franceses sob Vichy) e que teria o mérito de indicar que nem tudo é óbvio, definível - como diz o senso comum (ROLLEMBERG, 2008, p. 62). Nesse sentido, não deveríamos dividir os agentes históricos entre mocinhos e bandidos, pois haveria sempre posições nuançadas, ambivalentes. Trata-se de cautela muito ajuizada, mas é preciso convir que os historiadores que veem na sociedade, por exemplo, apenas repressores e reprimidos, mal se candidatam a receber qualquer crítica. Até mesmo as religiões, as artes e o senso comum contêm muitos exemplos de interpretações sutis, capazes de detectar ambivalências. Curiosamente, porém, quando Denise analisa a Ordem dos Advogados do Brasil (OAB), ela condena atitude que supõe censurável de Seabra Fagundes quando o jurista sugeriu que a $O A B$ não se pronunciasse sobre o artigo da Constituição de 1967 que isentava de apreciação judicial os atos praticados com base nos atos institucionais: "Como justamente a Ordem dos Advogados não devia se pronunciar a respeito?" - questiona, indignada, Denise Rollemberg. "Legalizava-se o ilegal, mais, o infame (... )", acusa (ROLLEMBERG, 2008, p. 77). Não é o caso de discutir a posição de Seabra Fagundes - homem de perfil democrático - mas de considerar que, nesse caso, tudo vai dito preto no branco, em tom de acusação e indignação, sem zonas cinzentas ou nuanças, sendo devidamente apontada a suposta contradição - e não a ambivalência - do denunciado.

Rodrigo Patto Sá Motta fez ampla pesquisa arquivística dos acervos dos órgãos de informações que operaram nas universidades e em seu livro As universidades e o regime militar trouxe revelações preciosas (MOTTA, 2014). Ele fez uso elaborado do conceito de

\footnotetext{
${ }^{14}$ Na ocasião, para registrar o debate, promovi um seminário sobre o tema. Duas intervenções importantes foram as de Lara (1992) e Gorender (1992).
} 
cultura política que, referido sobretudo aos grupos dirigentes, abrangeria traços que Rodrigo vai buscar em Roberto DaMatta, especialmente a tendência a privilegiar laços e fidelidades pessoais, autoridade pessoal, arranjos informais etc. Assim, por meio de “jogos de acomodação e conciliação", a repressão no ambiente universitário teria sido suavizada por meio de negociação, cooptação, relações pessoais e "jeitinho". O interessante é que Rodrigo supõe que "sob o influxo dessa cultura política brasileira, os governos militares estabeleceram políticas ambíguas, conciliatórias, em que os paradoxos beiravam a contradição" (MOTTA, 2014, p. 16). Ao longo do livro, Rodrigo dá vários exemplos de casos que identifica como contradição ou paradoxo. Por exemplo, a ditadura ao mesmo tempo perseguia professores de esquerda e os mantinha em seus empregos ou "enquanto certos líderes batalhavam pelo sucesso da reforma universitária (...) os comandantes da máquina repressiva intensificaram os expurgos" e assim por diante (MOTTA, 2014, p. 290). O livro de Rodrigo situa-se na melhor tradição das pesquisas que caracterizam a fase posterior à crise da História, já mencionada, e que se amparam no levantamento de evidências empíricas em dose maciça, mas deve-se louvar o esforço de seu autor de construir um arcabouço teórico que busca ultrapassar as platitudes da definição usual do conceito de cultura política.

De fato, Rodrigo Motta não apenas propõe uma noção de cultura política brasileira associada aos traços que caracterizam a interpretação de DaMatta, como também articula os supostos paradoxos com a noção de modernização conservadora ou autoritária. Trata-se, portanto, de quadro teórico complexo. Para Rodrigo, a natureza paradoxal seria o aspecto-chave do regime militar: o paradoxo residiria no fato de que o regime expressaria "impulsos conservadores e modernizantes que por vezes geram ações contraditórias". Assim, o sucesso das políticas econômicas modernizadoras colocaria em xeque as utopias conservadoras porque promoveria a mobilidade social. "Por outro lado, se levado às últimas consequências, o programa conservador oporia obstáculos à modernização, pois o expurgo de todos os 'suspeitos' e 'indesejáveis' (...) significaria perda (... ) para o projeto modernizante" (MOTTA, 2014, p. 288-289). Como se vê, há expectativas do autor muito negativas quanto à ação repressiva do regime. De fato, Rodrigo afirma que relações pessoais amenizaram riscos maiores "quando, pelas 
características do regime, seria de esperar atos repressivos fortes”. Ele também destaca que "chama atenção o número de episódios em que autoridades optaram por atos moderados e conciliatórios quando tinham à disposição o recurso a métodos repressivos" (MOTTA, 2014, p. 292). Rodrigo pressupõe que as "utopias conservadoras" almejavam a ausência de mobilidade social. Seria bastante difícil demonstrar que os militares, os empresários, os liberais conservadores, a classe média alta e demais setores que provavelmente comungam do que Rodrigo chama de utopias conservadoras não desejavam a mobilidade social, haja vista todos os programas em direção contrária adotados pelos governos militares, inclusive no âmbito estudado por Rodrigo, como o foi a reforma universitária, além do Mobral, do Prorural e outros. ${ }^{15}$

Por outro lado, o caráter absurdo da segunda hipótese (eliminação de todos os suspeitos) demonstra o porquê de ela não ter sido adotada: a repressão foi altamente seletiva, não havendo nessa seletividade nada de contraditório: de um lado, o governo podia arbitrar entre reprimir ou estimular dado setor, decidindo entre diretrizes diversas encaminhadas por suas agências, como ocorre em qualquer governo. O próprio Rodrigo dá exemplo quando menciona a Comissão Nacional de Moral e Civismo do MEC: suas demandas muito conservadoras nem sempre eram levadas em conta pelo governo, "mais preocupado em modernizar as universidades" (MOTTA, 2014, p. 289). Reprimir e modernizar ao mesmo tempo não era contraditório para o secretário-geral do Conselho de Segurança Nacional, que recomendava intensificar a repressão às lideranças estudantis e reformar a "estrutura arcaica" do ensino brasileiro. ${ }^{16}$

A repressão por vezes deixava de combater determinados setores por causa do impacto negativo que isso teria na opinião pública ou por sua desimportância relativa. Por exemplo, a censura de diversões públicas preocupava-se menos com o teatro do que com a televisão ou o cinema porque o público das peças era menor. Essa seletividade não era clara para Barbara Heliodora, crítica de teatro, que acusava o regime de ser contraditório porque o teatro não era considerado importante quando se falava de subvenções para a

\footnotetext{
${ }^{15}$ Para conhecer minha proposta sobre a existência de uma utopia autoritária, ver nova edição de Fico (2003) no prelo.

${ }^{16}$ Arquivo Nacional. Ata da $41^{\mathrm{a}}$ sessão do Conselho de Segurança Nacional, de 11 de julho de 1968. Livro 4, fl. 33.
} 
cultura, mas era visto como perigoso e subversivo pela censura moral (GARCIA, 2008, p. 177). Para o senso comum, esse tipo aparente de contradição também transparecia no cinema, pois a ditadura financiava e censurava filmes. Entretanto, entre 1969 e 1981, a Embrafilme produziu 140 filmes (com investimento direto, sem contar coproduções). Quatro desses filmes foram censurados por razões políticas e nove sofreram censura por razões políticas e morais (muitos outros foram censurados apenas por questões como nudez, palavrões etc., como vinha acontecendo desde antes da ditadura). Portanto, o impacto da ditadura na censura política do cinema foi pequeno. Além disso, no órgão que fazia a censura, a Divisão de Censura de Diversões Públicas (DCDP), havia cautela em relação aos filmes produzidos pela Embrafilme, justamente para evitar que a indústria cinematográfica nacional morresse (MARTINS, 2009, p. 103 e 123). Além da natural variedade de orientações das diversas agências do governo, trata-se da seletividade da repressão, não de contradição. De fato, militares radicais julgavam ser um paradoxo o fato de o governo conceder bolsa de estudo a "agitadores da área estudantil" (ALMEIDA, 2015, p. 93), mas isso era apenas a ação governamental se processando, sopesando perdas e ganhos, opiniões e pareceres diversos, como acontece em qualquer governo.

Além desse equacionamento problemático no que tange à noção de paradoxo ou contradição, Rodrigo Patto almeja superar a "simplista díade resistência versus colaboração" propondo uma tríade: resistência, adesão e acomodação. Quando trata dos jogos de acomodação, Rodrigo menciona que

a flexibilidade que permitiu tais estratégias de acomodação se devia, em parte, à heterogeneidade da base de apoio do regime militar, que contava com alas favoráveis à moderação no uso da violência. Entretanto, é importante também levar em consideração a influência da cultura política brasileira, marcada por tradicional tendência à conciliação e à acomodação. (MOTTA, 2014, p. 310-311)

Parece-me que, nesse momento, o arcabouço teórico de As universidades e o regime militar inconsolida-se: os jogos de acomodação decorrem da cultura política ou da heterogeneidade da base de apoio do regime militar? Se decorre de ambos, em que medida isso se dá? E se decorre de ambos, o esforço de construção do arcabouço teórico baseado na noção de cultura política foi pouco útil. O potencial explicativo da cultura 
política geral, brasileira, é problemática na medida em que ela possivelmente incidiria de maneira diferenciada nos jogos de acomodação, se considerado o universo do movimento sindical - para mencionar exemplo que Rodrigo cita - "cujos líderes provinham dos estratos sociais mais baixos" (MOTTA, 2014, p. 311). Do mesmo modo, a influência da mencionada cultura política teria deixado de existir no início dos anos 1980, quando das greves docentes de 1981, 1982 e 1984, que "representaram mudança política importante em relação aos anos anteriores" (MOTTA, 2014, p. 347).

Além disso, o auxílio que Rodrigo busca em "autores influentes no pensamento social brasileiro", como Roberto DaMatta, deixa de lado críticas importantes ao modelo proposto pelo famoso antropólogo. Dizer que DaMatta é influente é pouco, já que ele se tornou o último dos "explicadores do Brasil" - para usar expressão cunhada por Carlos Guilherme Mota - e conseguiu de fato impregnar-se no senso comum, na mídia, em todas as esferas, tanto ou mais do que Gilberto Freyre e o mito da democracia racial, ou Sergio Buarque de Holanda com a tese sobre o patrimonialismo brasileiro. Seus insights são reproduzidos por todos e assim admitidos como evidências, obviedades. No campo acadêmico, entretanto, há expressivas controvérsias que Rodrigo Motta talvez pudesse ter enfrentado. O sociólogo Jessé Souza, por exemplo, sustenta que, no trabalho de DaMatta, o “comportamento prático das pessoas é explicado por 'heranças culturais' misteriosas sem qualquer relação com as instituições que, na realidade, comandam nossa vida" (SOUZA, 2015, p. 76). Jessé identifica os jogos de acomodação, as relações pessoais ou o jeitinho com a noção de capital social e afirma que, quase sempre, quem tem capital econômico tem capital social. Por isso, segundo Souza,

quando DaMatta diz que o Brasil é o "país do jeitinho", ou seja, do acesso a relações pessoais poderosas que compõem o "capital social", na verdade está escondendo a questão principal para a crítica de qualquer sociedade moderna concreta, que é o desvelamento dos mecanismos que eternizam o acesso privilegiado de alguns grupos e classes aos capitais impessoais, seja ele econômico ou cultural. (SOUZA, 2015, p. 86) 
É evidente que tais críticas, entre outras, problematizam muito a utilização das contribuições de DaMatta para a construção do conceito de cultura política brasileira nos termos que propõe Rodrigo Patto Sá Motta. Isso sem mencionar o caráter estereotipado dessas noções sobre "o brasileiro". Ademais, a ideia de que a sociedade brasileira seria marcada por especificidade negativa situa o país em condição desvantajosa na comparação com outros países que, supostamente, viveriam uma modernidade ideal, isenta dos vícios que flagelariam o Brasil. ${ }^{17}$ A negatividade adviria do influxo da cultura política que levaria a essas práticas marcadas pelo recurso aos laços pessoais, à autoridade pessoal, aos arranjos informais etc. Tratar-se-ia de uma sociedade prémoderna, atrasada. Tais práticas, entretanto, segundo Rodrigo Motta, teriam permitido o abrandamento da repressão e nisso haveria a mencionada acomodação capaz de amainar o que poderia ser uma violência descontrolada. Além de vivermos uma ditadura, teríamos a sociedade (ou alguns grupos?) marcada pelo jeitinho. $\mathrm{O}$ traço negativo da acomodação, do personalismo, não é discutido por Rodrigo. $O$ caráter crítico daquele processo estaria na alegada contradição entre repressão e modernização, pois o regime teria sido "ao mesmo tempo destrutivo e construtivo", haveria um "outro lado", como afirma cautelosamente Rodrigo (MOTTA, 2014, p. 7), ou seja, um lado bom - digo eu - como se pudesse haver algo bom em um regime de supressão das liberdades.

\section{4) Modernizaç̃ão Conservadora}

Assim, a grande contradição - como não poderia deixar de ser, haja vista o subtítulo do livro de Rodrigo - estaria no "paradoxo central do regime militar - a modernização autoritária-conservadora" (MOTTA, 2014, p. 293), conceito que se tornou lugar-comum reproduzido por muitos analistas do regime militar exatamente nessa chave desenvolvida por Rodrigo Motta, a da pretensa contradição entre um regime militar (que aparentemente é pensado como devendo ser 100\% repressor e reacionário) e um projeto de desenvolvimento tido como modernizante.

\footnotetext{
${ }^{17}$ A suposta singularidade brasileira seria difícil de entender, conforme Tom Jobim destacou no dito famoso “O Brasil não é para principiantes". Sintomaticamente, a frase foi usada para intitular livro em homenagem a Roberto DaMatta. Ela também serve de epígrafe ao livro de Marco Antonio Villa (2014) e é a última frase do livro de Marcos Napolitano (2016), o que mostra a aceitação generalizada dessa ideia.
} 
Todos conhecemos a origem do conceito de modernização conservadora e não é o caso de maçar o leitor com uma exegese do livro de Barrington Moore Jr., publicado no remotíssimo ano de 1967 quando a teoria da modernização já vinha sendo criticada. Entretanto, convém lembrar que a análise conduzida por Moore, com elevado grau de generalização e abstração, pretendeu estabelecer regras universais com base em hierarquização que definiu casos ótimos ou modelares (as "modernas democracias industriais" da Inglaterra, da França e dos Estados Unidos da América) e casos em que, devido ao impulso burguês alegadamente frágil, uma espécie de "coligação reacionária" entre classes comerciais, industriais emergentes e fundiárias teria sido responsável pelas políticas de modernização em direção à sociedade industrial (casos do Japão e Alemanha). "Mas o resultado [nesses casos,] após um período breve e instável de democracia, tem sido o fascismo (MOORE JR., 1983, p. 5). Esse tipo de coligação também se verificaria em outros lugares de maneira variada. Nos casos em que houve estabilidade do arranjo, pode ter ocorrido "período prolongado de governo conservador e mesmo autoritário, sem, contudo, cair no fascismo". Barrington Moore Jr. prossegue afirmando que alguns desses governos conservadores ou autoritários "executaram uma revolução mais ou menos pacífica, vinda de cima, que muito os fez avançar, no sentido de se tornarem países industriais modernos". Foi nesse contexto que ele cautelosamente registrou, em ligeira nota de rodapé, "com base num conhecimento confessadamente inadequado", que esse poderia ser o caso de países latino-americanos. Porém, note-se que a possível analogia com países latino-americanos - feita, como se vê, muito lateralmente - não se deu em passagem na qual o sociólogo norte-americano tratasse da modernização ou industrialização, mas quando ele falava de governos autoritários que adquiriram características democráticas (especialmente um parlamento com poderes limitados) e que buscaram a democracia que, afinal, se estabeleceu de maneira instável. Ele cita a República de Weimar, o Japão da década de 1920 e a Itália de Giovanni Giolitti para, então, concluir: "a porta para os regimes fascistas foi aberta pela incapacidade de estas democracias enfrentarem os problemas graves da época e a sua relutância ou incapacidade de introduzir alterações estruturais fundamentais" (MOORE JR, 1983, p. 431, 432 e nota 4). 
Apesar da cautela de Barrington Moore Jr. e do enfoque negativo com que ele fez sua ligeira analogia, a ideia da modernização conservadora passou a ser adotada por muitos analistas do regime militar brasileiro. Isso tem sido feito de maneira muito variada, algumas vezes com referência explícita a Social Origins of Dictatorship and Democracy ou, mais frequentemente, como uma evidência, algo sobre o qual não é necessário refletir: uma ditadura (conservadora, autoritária) que, apesar de tudo, promoveu a industrialização, a modernização. Logo, modernização conservadora ou autoritária.

Nesse passo, convém alertar o leitor de que minha posição, contrária à ideia de contradição e paradoxo, é minoritária e que minha rejeição ao uso do conceito de modernização conservadora provavelmente é atitude isolada, tão ampla é a aceitação dessas ideias. A possibilidade de eu estar errado, portanto, é grande.

Seja como for, a ideia de modernização conservadora - suas variações ou rarefações - logo foi adotada por diversos analistas e persiste até hoje como explicação da ditadura. Fernando Henrique Cardoso, poucos anos depois da publicação do livro de Moore, tratando da questão da dependência na famosa exposição que fez, em abril de 1971, em seminário na Universidade de Yale, mencionou a suposta contradição entre o “movimento politicamente reacionário de 1964" e a modernização do Estado, o incremento do setor público da economia e a integração do país ao capitalismo internacional (CARDOSO, 1972, p. 71). Marcelo Ridenti, em sua aclamada tese defendida em 1989 e publicada em 1993 (RIDENTI, 1993, p. 18), usou a expressão de maneira indistinta. Em 1997, Ridenti a utilizou como indicadora de contradição entre "crescimento rápido das forças produtivas" e injustiça social combinada com supressão de liberdades (RIDENTI, 1997, p. 20). Em 2003, em capítulo sobre cultura e política nos anos 1960-1970, elaborou um pouco mais a ideia, persistindo no lugar-comum (na acepção de tópico) do paradoxo, não adotando o sentido original proposto por Moore. Essa, provavelmente, é a origem do insight teórico de Rodrigo Motta. De fato, segundo Ridenti

a atuação cultural do regime civil-militar também implicou a modernização-conservadora da educação, com a massificação (e a degradação) do ensino público de primeiro e segundo graus, o incentivo ao ensino privado e a criação de um sistema nacional de apoio à pósgraduação e à pesquisa para as universidades, nas quais a ditadura 
encontrava alguns dos principais focos de resistência, que reprimiu duramente, mas sem deixar de oferecer uma alternativa de acomodação institucional. (RIDENTI, 2003, p. 156)

Nesse trabalho de Ridenti já estavam presentes o suposto paradoxo e a possibilidade da acomodação nas universidades que Rodrigo desenvolveria. Poucos anos depois, Ridenti retrabalhou esse texto e qualificou como irônico o alegado paradoxo daquilo que ele então passou a identificar como modernização autoritária e não mais conservadora. Esse ato linguístico de Ridenti de caracterizar como irônico o paradoxo é aparentemente menor, mas importa muito: conforme os estudos de retórica estabelecem, a figura do paradoxo, encontradiça nas análises sobre a ditadura, tem na figura da ironia importante reforço. ${ }^{18} \mathrm{~A}$ ironia frequentemente leva a uma espécie de paroxismo do distanciamento, porque pode tender à "superioridade pesarosa" de quem afirma sobre o passado: “- Eles não se davam conta do que realmente estava acontecendo!". Mas a combinação desprevenida do paradoxo com a ironia também pode levar à estupefação, como já vimos no episódio da indignação de Denise Rollemberg contra Seabra Fagundes. Ridenti, do mesmo modo, em 2003, falou em acomodação como adaptação conformada. Ele chamou atenção para o que identificou como o "declínio público da intelectualidade brasileira de esquerda" e acusou os intelectuais, que outrora combateram a ditadura, de adaptação à nova ordem, no que seria o triunfo da concepção neoliberal do indivíduo (RIDENTI, 2003, p. 159-161). Em 2008, reiterou que a modernização autoritária ofereceu alternativa de acomodação a setores de oposição. Tal acomodação, juntamente com a repressão, foi capaz de "neutralizar eventuais sonhos revolucionários, que conviveriam com e cederiam espaço ao investimento na profissão, no qual prevaleceria a realidade cotidiana da burocratização e do emprego" (RIDENTI, 2008, p. 36-37). Irônico e indignado, acusou o intelectual acomodado e neoliberal de apenas mirar

\footnotetext{
${ }^{18}$ Observe-se a recorrência de frases como, por exemplo, "o ano que não terminou" (anos terminam); "golpe dentro do golpe" (não se golpeia a si mesmo); "batalha de Itararé" (ou "de saliva" ou "de telefonemas", para caracterizar o golpe - que deveria ser violento); "o Exército dormiu janguista e acordou revolucionário" (não se muda de posição desse jeito). Entre muitos analistas do regime militar, há acentuada preferência pelas figuras do paradoxo e da ironia, sobretudo as que apequenam os militares. Na série de reportagens encomiásticas que fez em 1964, o jornalista José Stacchini caracterizou o golpe como "uma rebelião tão contraditória e curiosa quão curioso e contraditório é este Brasil” (STACCHINI, 1965, p. 1).
} 
o movimento da rua "instalado na janela à prova de balas de seu confortável gabinete, com vista para o mar, que não cansa de mirar, aguardando notícias da última moda intelectual no exterior, ou a oportunidade de conferi-la pessoalmente em Paris, Londres ou Nova York" (RIDENTI, 2003, p. 160).

Afora a elaboração de Marcelo Ridenti, que seria apropriada e ampliada da maneira que vimos por Rodrigo Motta, as outras referências ao conceito são bastante rarefeitas. Daniel Aarão Reis Filho, por exemplo, menciona a expressão após considerar análises de conjuntura equivocadas da esquerda nos anos 1960 sobre suposta crise que atingiria o capitalismo e a ditadura: "nessas construções (...) era impossível perceber que, no emaranhado contraditório das políticas da ditadura, tomava corpo um processo de modernização conservadora" (REIS, 2014, p. 61). Marco Antonio Villa fala em "ação econômica modernizadora" (VILLA, 2014, p. 376). Marcos Napolitano diz que "o caminho da modernização" seria marcado pelo viés da "segurança e desenvolvimento" (NAPOLITANO, 2016, p. 7-8).

A ideia de modernização conservadora tem a força do senso comum: quando se pensa a ditadura brasileira, é fácil identificar a repressão, o conservadorismo, o autoritarismo, por um lado e, por outro, o crescimento econômico do "milagre" brasileiro, as obras de infraestrutura, os avanços nas telecomunicações etc. Para o senso comum, uma ditadura deveria corresponder a período de trevas, de completa estagnação, devendo ser regressiva e inteiramente repressiva. Daí ser tão comum a pergunta que os jornalistas nos fazem sobre ter havido um "lado bom" no regime militar brasileiro, justamente o lado do crescimento econômico, das obras de infraestrutura etc. Isso seria aparentemente contraditório, difícil de compreender. Ora, o conceito de modernização conservadora de Barrington Moore Jr. não tem como vetor analítico principal essa questão da contradição. Buscando contrapor-se às vertentes ainda predominantes das já então claudicantes teorias da modernização, Moore tentou formular uma espécie de neomarxismo, na verdade muito impreciso e criticado, mas, de qualquer forma, valorizador do conceito de classe social como determinante para a discussão de modernização. 
Associado à noção de paradoxo, o conceito de modernização conservadora ou autoritária torna-se ainda mais frágil do que a proposição original de Moore porque carece de historicidade. Tenho dito que "não devemos reduzir a história do Brasil entre 1964 e 1985 à história da ditadura militar”. Essa frase é apenas um jogo de palavras com o qual, não obstante, tenho tentado chamar atenção para o fato de que nem tudo o que aconteceu naqueles anos decorre da circunstância de ter havido uma ditadura militar. Muitos exemplos de fenômenos tipicamente referidos à ditadura militar poderiam ser mencionados como tendo sua origem, entretanto, em etapas anteriores. Isso aconteceu com a censura de diversões públicas, com a propaganda política, com o Conselho Federal de Cultura, com várias fórmulas no campo político - diversos casos que não podem ser detalhados no momento. ${ }^{19}$ O exemplo sempre mencionado é o caso do "milagre" brasileiro. Entretanto, a economia brasileira chegou a crescer acima de sua média histórica em outros períodos a partir de 1940. Houve fases de elevadas taxas de crescimento logo após a Segunda Guerra Mundial e no período do Plano de Metas, além do "milagre". Por outro lado, no final dos anos 1970, durante a ditadura militar, o crescimento do PIB passou a ter médias baixas (VIEIRA, 2008, p. 19). Ou seja, a modernização - aqui entendida como crescimento do PIB e suas consequências - não decorreu do regime autoritário; vinha sendo construída havia décadas. Note-se que não estou propondo mobilizar condicionais contrafáticos do tipo "teria havido crescimento mesmo que não houvesse ditadura". O que estou afirmando é que o crescimento que houve durante o período não foi apenas uma decorrência das ações dos governos militares, devendo também ser lido em duração mais longa.

Além de tudo isso, vale lembrar o que disse Marilena Chauí muitos anos atrás:

a ideia de atraso ou de tardio implicitamente pressupõe, como contraponto, um "modelo" de sociedade completamente realizado ou desenvolvido, de sorte que a história passa a ser lida como processo de modernização e esta, como progresso e aproximação gradativa do atrasado rumo ao desenvolvido. (CHAUÍ, 1978, p. 27)

\footnotetext{
${ }^{19}$ Para permanências do Estado Novo na ditadura militar, ver Fico (2011).
} 
De fato, impressiona que essa dimensão por assim dizer ideológica das teorias da modernização não seja ao menos considerada por quem queira persistir adotando perspectiva que já foi tão criticada. Tal visão, quando levada ao limite, situa o Brasil em patamar de atraso institucional cujas causas parecem estar em uma incapacidade geral da sociedade. É o que se vê no trabalho de Ronald Schneider segundo o qual o "processo incompleto de modernização" do Brasil e sua "instabilidade política" - decorrente do “desenvolvimento muito lento das organizações e instituições políticas" - são marcados pela "fragilidade da comunidade política", pelo “inadequado nível de institucionalização", pela "fraqueza e heterogeneidade dos partidos políticos" e assim por diante. (SCHNEIDER, 1971, passim). Schneider não se baseou em Moore, mas no economista norte-americano Samuel Huntington, que sustentava ideias desse tipo e chegou a vir ao Brasil para seminários acadêmicos e conversas com integrantes do governo Médici em 1972. Em entrevista ao Jornal do Brasil, na época, Huntington referendou a frase atribuída a Delfim Netto de que primeiro era preciso deixar o bolo crescer para depois reparti-lo: Huntington disse que era essencial restringir as reivindicações sociais para permitir o desenvolvimento econômico. ${ }^{20}$ Enfim, enquanto não fôssemos capazes de superar nossas carências institucionais, nunca chegaríamos à modernidade das democracias competitivas e sofisticadas e estaríamos fadados a alternar entre a "democradura" e a "ditabranda", para lembrar as lamentáveis expressões divulgadas, na época, por outro cientista político norte-americano, Philippe Schmitter, uma das quais foi retomada muitos anos depois pelo desavisado autor de polêmico editorial da Folha de S. Paulo de 17 de fevereiro de 2009 (SCHMITTER, 1971, p. 392).

\section{5) Natureza de classe}

A crítica que os historiadores marxistas fizeram aos assim chamados revisionistas de não lançarem mão do conceito de classe social foi quase um lamento. Marcelo Badaró, por exemplo, depois de lembrar que Moniz Bandeira afirmou que o golpe de 1964 foi um

\footnotetext{
${ }^{20}$ Jornal do Brasil. Rio de Janeiro, 22 de outubro de $1972.1^{\circ}$ Caderno, p. 18.
} 
episódio da luta de classes, indagou: "teria a historiografia mais recente dúvidas em relação a isso?" (MATTOS, 2008, p. 262). É pergunta retórica, naturalmente. Alguns anos depois de expressar essa dúvida, Marcelo fez críticas à perspectiva analítica de Daniel Aarão Reis Filho que, anunciada pelo menos desde 2010, acabaria por inspirar pesquisas e publicações. Segundo o enfoque defendido por Daniel, teria havido um tipo de consenso em favor da aceitação do regime militar capaz de gerar apoio e/ou minar eventuais resistências (REIS, 2010, p. 182, nota 1 e MATTOS, 2014, p. 88). Foi essa perspectiva que inspirou a obra $A$ construção social dos regimes autoritários que, por isso mesmo, também foi criticada por Marcelo Badaró Mattos (ROLLEMBERG; QUADRAT, 2010 e MATTOS, 2014, p. 89).

Em 2014, Daniel elaboraria seu enfoque afirmando que civis apoiaram ou se subordinaram por várias razões ao regime. Desse modo, "a ditadura no Brasil, até pelo longo período que durou, foi uma construção histórica. Impossível compreendê-la sem trazer à tona suas bases políticas e sociais - múltiplas e diferenciadas” (REIS, 2014, p. 128).

Nos elementos extratextuais do livro organizado por Demian Bezerra de Melo, outros autores marxistas também registraram breves críticas aos alegados revisionistas sobre a questão da classe: Virgínia Fontes, no prefácio, fala em "tentativa de fazer desaparecer por mágica as classes sociais e suas lutas"; Renato Lemos, na orelha, sustenta que os chamados revisionistas "negam validade heurística a conceitos associados à luta de classe, propondo outros, voltados para a descaracterização da natureza classista das sociedades"; Gilberto Calil, na quarta capa, garante que os acusados sustentam visão conservadora, negadora dos conflitos e teoricamente frágil, além de não usarem os conceitos de classe e de luta de classes (MELO, 2014). As críticas registram a ausência. Desse modo, cabe perguntar: por que os criticados deveriam usar o conceito de classe social? Que vantagens cognitivas adviriam desse uso? Como eles deveriam superar as dificuldades e limitações do conceito de classe social apontadas por críticos serenos e admitidas por marxistas reconhecidos? Nada disso é dito.

Sem realizar debate aprofundado sobre a questão das classes sociais no contexto do golpe de Estado de 1964 e do regime subsequente, essa polêmica - algo restrita institucionalmente à Universidade Federal Fluminense - ficou prisioneira da moldura 
estabelecida por Daniel Aarão Reis Filho, cuja preocupação é identificar quem apoiou o golpe e, por imobilismo ou por apatia, colaborou para a sustentação e continuidade do regime. Esse propósito tem objetivos que ainda analisarei, mas é de algum modo limitado, classificatório e, seja como for, não descarta, necessariamente, o uso do conceito de classe social.

Quando os historiadores marxistas registram a ausência do conceito de classe social eles não parecem estar defendendo a necessidade da análise marxista do golpe de 1964 e do regime militar, na medida em que não apresentam as desvantagens decorrentes da consideração da sociedade brasileira de então conforme os parâmetros tidos como revisionistas. Digo isso porque há, de fato, problema analítico bastante central que demandaria equacionamento dependente de melhor entendimento da teoria das classes sociais e que, apesar de ter sido muitíssimo discutido, desde pelo menos o início dos anos 1980, ainda carece de resolução. Refiro-me, evidentemente, ao problema teórico das classes médias e aos estudos de Décio Saes. Em ensaio muito conhecido, publicado em 1981, Décio Saes, tratando do golpe de 1964, afirmou que "a classe dominante irá encontrar a sua 'massa' contrarrevolucionária no seio da classe média". Além disso, sustentou que essa instrumentalização foi feita pelos "setores mais arcaicos, retrógrados e conservadores da classe dominante: a burguesia comercial e os proprietários fundiários" (SAES, 1981, p. 499-500), afirmação que contém ecos evidentes da ideia central de Barrington Moore Jr. Alguns anos depois, João Roberto Martins destacou as dificuldades de caracterização das classes médias: "o apoio, a hesitação e mesmo a oposição (esta provocada pelo medo à proletarização) coexistem no seio da 'massa' da baixa classe média” (MARTINS FILHO, 1987, p. 66). Portanto, não faltam problemas: como inserir alta e baixa classes médias na hierarquização e conflitividade social das relações de subordinação e dependência típicas do capitalismo, isto é, como se correlacionam, em termos da luta de classes, a classe dominante, o proletariado e as classes médias? Será preciso dizer que esse velho problema teórico (e sua irresolução) é uma das fragilidades da teoria social global marxista? Não basta, evidentemente, clamar pelo uso do conceito de classes sem ao menos enfrentá-lo.

Entretanto, o que eu dizia é que os críticos marxistas não parecem essencialmente 
incomodados com a não utilização do conceito de classe, mas com a ocultação do fato de que, em 1964, alguém foi derrotado. Por vezes, realmente, os autores criticados descuidam-se e falam genericamente de apoio da sociedade e não de apoio de parte da sociedade. Do ponto de vista empírico, isso é um erro; do ponto de vista cognitivo, relativamente irrelevante: o que define a natureza dos eventos da história política não é a rede de apoios com que contam, mas os sujeitos históricos que os engendram. O golpe foi apoiado por muitos, mas a movimentação de tropas militares foi autorizada pelo governador Magalhães Pinto e, com a deliquescência do governo, o Congresso Nacional decretou a vacância do cargo de presidente da República: políticos, militares e parlamentares deram o golpe com o apoio, o entusiasmo ou para o gáudio ou desespero de muitos setores. Falar simplesmente em apoio é impreciso, pois há diferenças enormes entre a ação enfurecida de Carlos Lacerda armado e vestido com sua japona preta no Palácio Guanabara, ou a pressão das marchas das mulheres de classe média com seus rosários, o apoio institucional da Igreja católica, o beneplácito da OAB, o clamor da imprensa ou a simples satisfação política dos que concordavam com o que viam e foram para as ruas festejar ou incendiar a UNE. Essa minha leitura, se traduzida para o marxismo, mutatis mutandis, se expressaria segundo a fórmula de ampla base social de um movimento golpista liderado pela burguesia. A questão do apoio, diga-se de passagem, não está isenta de controvérsias, pois ainda é preciso melhor considerar evidências empíricas como as pesquisas de opinião pública que dão forte respaldo a João Goulart e, convenhamos, são dados tão ou mais eloquentes do que o apoio ao golpe de entidades como a OAB ou das Marchas da Família, com Deus, pela Liberdade, que, apesar de numerosas, também foram estimuladas pela rede altamente capilarizada da Igreja católica, tendo o seu quê de manipulação. ${ }^{21}$

Os militares, evidentemente, sempre estiveram preocupados com o apoio ao regime da parte dos setores com que pudessem contar. O ministro do Exército, durante reunião do Conselho de Segurança Nacional, em 1968, reconheceu que a "revolução" perdia apoio da opinião pública. O ministro da Aeronáutica preocupava-se com as mulheres de classe média, presentes nas famosas marchas de 1964 . O resultado da

\footnotetext{
${ }^{21}$ Sobre as pesquisas de opinião pública em 1964, ver Dias (2014).
} 
ofensiva da classe dominante contra o proletariado e, por isso, "um episódio da luta de classes". De fato, o golpe não atingiu apenas o trabalhismo, ao contrário do que sustentou, anos atrás, Maria Celina D’Araujo, quando destacou que "o golpe era contra o trabalhismo janguista e contra as alianças e os compromissos que o PTB fazia com a esquerda civil e militar". Como se sabe, Maria Celina foi seguida, com variações, por outros autores (D'ARAUJO, 1996, p. 140; FERREIRA, 2003, p. 400; NAPOLITANO, 2015, p. 194; NAPOLITANO, 2016, p. 53 e 66). É evidente que, por se tratar de movimento que objetivava garantir e aprofundar a inserção do Brasil no capitalismo - obviedade que salta aos olhos - o golpe de Estado de 1964 e o regime que o sucedeu atingiram, mais do que o trabalhismo e o comunismo, todos aqueles que, no capitalismo, segundo a ótica marxista, estão submetidos às relações de subordinação e dependência que marcam a típica dominação desse modo de produção. Ou seja, o golpe atingiu o proletariado. Nesse sentido - ainda segundo a ótica marxista - o Estado brasileiro, antes e depois do golpe de 1964, tinha uma natureza de classe. ${ }^{23}$ Portanto, não se trataria de reconhecer a natureza de classe do golpe de 1964 e do regime militar, já que a natureza de classe do Estado brasileiro nunca esteve em efetivo risco (não obstante a opinião em contrário daqueles que viam como possível a revolução comunista no pré-1964). ${ }^{24}$ Entretanto, toldado pela discussão da aceitação (apoio) do golpe e da ditadura levantada por Daniel Aarão, Marcelo Badaró reclama reconhecimento para o "sentido de classe do regime". O que temos, então? De um lado, Daniel afirma que o golpe e a ditadura receberam apoio de importantes setores da sociedade (como Fernando Henrique Cardoso, Décio Saes, René Armand Dreifuss e outros pesquisadores vêm dizendo desde os anos 1970); de outro,

\footnotetext{
${ }^{22}$ Arquivo Nacional. Ata da 41 $1^{\text {a }}$ Sessão do Conselho de Segurança Nacional, em 11 de julho de 1968. Livro 4, fls. 15 e 19.

${ }^{23}$ Para consultar a clássica tese sobre o deslocamento dos setores identificados como nacional-burguês e estatista-desenvolvimentista em favor do setor mais internacionalizado da burguesia, ver Cardoso (1972, p. 67-69). Para versão que supõe a crise do chamado Estado populista e a alegada incapacidade da burguesia de defender seus interesses, ver Oliveira (1976, p. 47).

${ }^{24}$ Fernando Henrique Cardoso, em fórmula criativa, garantiu que havia conjuntura pré-revolucionária que, entretanto, dificilmente resultaria em revolução (Cardoso, 1972, p. 67). Jacob Gorender também supunha que o golpe teve "caráter contra-revolucionário preventivo" (Gorender, 1987, p. 66-67).
} 
Marcelo Badaró sustenta que o golpe e a ditadura são vitórias da burguesia, como ninguém jamais negou. Realidades não contraditórias e consabidas.

A dimensão política desse debate é admitida por Badaró: “move-me uma preocupação de fundo eminentemente político". Para ele, o suposto culturalismo desqualifica referências políticas da esquerda (MATTOS, 2014, p. 93 e seguintes). Trata-se de questão legítima e ela está presente também no texto de Demian quando ele afirma que pretende problematizar "o uso público do conhecimento histórico entendido como parte das disputas pela hegemonia" (MELO, 2014, p. 157). Apesar de legítima, a questão me parece supérflua. Para citar marxista famoso, lembre-se de que Eric Hobsbawm escreveu, certa vez, que "os historiadores profissionais produzem a matéria-prima para o uso ou abuso dos não-profissionais" (HOBSBAWM, 1998, p. 285). Certamente não temos controle sobre os usos sociais que possam ser feitos sobre o conhecimento que produzimos. Entretanto, temos toda a responsabilidade sobre a densidade teórica dos debates que propomos.

\section{2) Deslocamento de sentido}

A velha questão da tensão entre memória e história aparece na crítica marxista mencionada como alegada responsabilidade social que os historiadores criticados teriam por fragilizar as perspectivas da esquerda na medida em que eles alimentariam o discurso da direita. Já entre os historiadores acusados de revisionismo, o problema diz respeito à suposta necessidade que os historiadores teriam de apontar a verdade encoberta pela memória prevalecente sobre a ditadura - propósito igualmente dificultoso.

De fato, há problema básico na conhecida perspectiva proposta por Daniel Aarão Reis Filho que se pode distinguir com facilidade na obra realizada sob sua inspiração, $A$ construção social dos regimes autoritários. Trata-se da crítica da memória prevalecente e da suposição de que tal predomínio contou com a colaboração da produção acadêmica. Ao menos, é o que fica patente quando se observa duas motivações iniciais das organizadoras, Denise Rollemberg e Samantha Viz Quadrat, registradas na apresentação 

instituições e práticas coercitivas e manipulatórias". A segunda é a suposição das autoras de que “(...) pouco se pesquisou e escreveu no sentido de compreender as relações da sociedade com o regime inaugurado em 31 de março" (ROLLEMBERG; QUADRAT, 2010, p. 11-12). Bem, não há nada de estranho no surgimento de memórias confortáveis após eventos traumáticos. Essa é reação natural das sociedades e costuma ser um dos caminhos mais comuns, muito embora a memória traumática ou a frustração também ocorram. Seja como for, cabe aos historiadores deslindar a gênese desse complexo fenômeno. Não há de ser frutífera a perspectiva segundo a qual a construção de tais memórias tenha obedecido a desígnios inconfessáveis, até porque esses processos não obedecem a parâmetros de intencionalidade. Mas, se o estranhamento inicial - embora injustificado - diz respeito à memória, a segunda constatação se refere às pesquisas acadêmicas, que pouco teriam se debruçado sobre as relações entre sociedade e ditadura. Não vou atormentar o leitor com longa lista de pesquisas que trataram dessa relação, pois provavelmente Denise e Samantha estão cobrando mais pesquisas sobre aqueles que apoiaram, no caso do Brasil, o golpe e a ditadura. Meu ponto não diz respeito a esse lapso, mas ao fato de que, como já disse, não temos controle sobre o uso social que se pode fazer sobre nossa produção. Aliás, é bastante pretensioso supor que foi a produção acadêmica que gerou qualquer memória confortável, sendo mais provável que isso obedeça a outros influxos. No caso do Brasil, quando houve, segundo Daniel Aarão Reis Filho, o "deslocamento de sentido" gerador de tal memória, a produção acadêmica sobre a ditadura era incipiente. Aliás, foi o próprio Daniel quem sugeriu que a "notável reconstrução" se deu no contexto da anistia, até mesmo para incorporar os presos políticos acusados de crimes de sangue, que, assim, "mereciam a anistia” e podiam, “inclusive, postular reparações morais e indenizações materiais ao Estado". Daniel não explica a persistência desse deslocamento de sentido ao longo das diversas conjunturas que vão da época da Lei da Anistia de 1979 até o momento em que a Comissão da Anistia, em 2001, foi criada com a capacidade de prover reparações materiais (REIS, 2004, p. 49).

\footnotetext{
${ }^{25} \mathrm{~A}$ obra se divide em volumes sobre Brasil/América Latina; Europa e Ásia/África.
} 
Foi Denise Rollemberg quem trabalhou mais detidamente a perspectiva. No livro $A$ construção social dos regimes autoritários, ela confrontou a memória que se construiu sobre a Associação Brasileira de Imprensa ( $\mathrm{ABI}$ ) com a pesquisa que realizou sobre essa instituição que, como se sabe, depois do $\mathrm{Al}-5$, aproximadamente, se tornou bastante crítica em relação à ditadura, apesar de certa omissão no momento do golpe. A narrativa de Denise é enriquecida com figuras de ironia, linguagem hiperbólica e ênfases que destacam palavras grifadas, recursos que lhe conferem vivacidade e brilho, mas que, por vezes, levam à imprecisão ou generalização. Assim é que, quando descreve a memória confortável já mencionada, ela acusa "a sociedade" de ter construído "a imagem de si mesma como essencialmente democrática, que repudiara o arbítrio, desde o início, desde sempre, numa luta intransigente". Do mesmo modo, afirma que essa memória coletiva "absolve" aqueles que apoiaram o regime (ROLLEMBERG, 2010, p. 2 e 131. Grifado no original). O problema, portanto, não está na correta identificação do fenômeno da memória confortável, nem na pesquisa histórica que identifica agentes e/ou instituições que apoiaram o regime, mas no enfoque que se pauta por procedimentos de acusação e culpa.

A ideia de deslocamento de sentido de Daniel Aarão é interessante justamente porque trata dessa memória confortável. O uso da palavra deslocamento poderia ser discutido, pois há aí a pressuposição de que havia sentido anterior que foi movido de lugar, quando, na verdade, se trata da construção de memória original. Seja como for, a crítica de Daniel é conhecida: ele entende que as esquerdas que se supunham revolucionárias passaram, no contexto da anistia, a se reconhecer e serem reconhecidas como integrantes da resistência democrática, quando, originalmente, haviam sido defensoras da revolução, não da democracia. ${ }^{26}$ Daniel Aarão diz que esse entendimento acabou por se fixar como "verdades irrefutáveis, processos históricos objetivos, e não versões consideradas apropriadas por seus autores" (REIS, 2014, p. 133). Ele identifica aquelas que seriam as fontes do deslocamento. Uma delas seria o livro de Fernando Gabeira, supervalorizado e ironizado por Daniel como "versão simpática e bem-

\footnotetext{
${ }^{26}$ Essa também é a opinião de Marco Antonio Villa, para o qual os grupos da luta armada foram hegemônicos na construção da memória e "transformaram a defesa da ditadura do proletariado em defesa da democracia” (VILLA, 2014, p. 386).
} 
humorada" da "saga guerrilheira" que teria sido capaz de gerar "uma atmosfera de indulgência e de compreensão" (REIS, 2014, p. 9). O livro de Gabeira foi publicado em 1979. Dezoito anos depois, o cineasta Bruno Barreto lançou filme com o mesmo nome, livremente baseado no livro, sem ser fiel aos fatos e pessoas envolvidos no sequestro planejado por Franklin Martins e Daniel Aarão Reis Filho, que integravam a Direção Geral da Dissidência Comunista da Guanabara (SILVA, 2009, p. 214). Ex-militantes da esquerda e outros críticos receberam mal o filme, que acabou sendo indicado ao Oscar de melhor filme estrangeiro. Daniel organizou a publicação de livro que reuniu artigos criticando o filme (REIS FILHO, 1997). Para ele, o livro de Gabeira teria feito sucesso porque "a maioria dos leitores" desejava a "atitude distanciada, crítica, irônica” de sua narrativa. Referindose de modo irônico, crítico e distanciado ao livro de Gabeira e também ao de Zuenir Ventura, Daniel afirmou: "estes autores foram a expressão mais acabada de seu tempo (...) que importa tenham cometido deslizes na narração das histórias?" (REIS FILHO, 1997, p. 36). Parece que importa muito, haja vista todo o empenho da crítica. Como se vê, para Daniel, a sociedade estava predisposta a acolher versões confortáveis: “Outras memórias (...) não mereceriam a mesma acolhida porque não estavam sintonizadas com as aspirações majoritárias ao apaziguamento e à conciliação" (REIS, 2014, p. 9). A versão de Gabeira seria a versão da conciliação (REIS, 2008, p.16).

A publicação do livro Brasil: nunca mais também é vista como fonte da memória confortável na medida em que expôs as sevícias, as torturas e supostamente elaborou o discurso da vitimização: "a sociedade brasileira viveu a ditadura como um pesadelo que é preciso exorcizar" (REIS, 2014, p. 13). ${ }^{27}$ Essa memória se tornaria, afinal, prevalecente e candidata à história oficial da ditadura por meio do projeto Memórias Reveladas. ${ }^{28}$ Segundo Daniel, “faz parte também da reconstrução da história a constituição, desde 2012, da chamada Comissão Nacional da Verdade” (REIS, 2014, p. 13). Em alguns

\footnotetext{
${ }^{27}$ O projeto consistiu na cópia sigilosa, a partir de 1979, de mais de setecentos processos que tramitavam pela Justiça Militar, já que os advogados podiam retirá-los por 24 horas. Teve o apoio do Conselho Mundial de Igrejas e da Arquidiocese de São Paulo. A análise e catalogação das informações gerou doze volumes e um resumo foi publicado em 1985 pela editora Vozes. O material está na Universidade de Campinas.

${ }^{28}$ Projeto criado em 2009 pela Casa Civil da Presidência da República com o nome de "Centro de Referência das Lutas Políticas, 1964-1985" tendo como principal escopo os acervos documentais da ditadura custodiados pelo Arquivo Nacional.
} 

palavras, o silêncio como forma de memória” (REIS, 2014 p. 136).

A afirmação sobre a predisposição da sociedade brasileira (como um todo?) para aderir a esse discurso ou memória resta por ser comprovada. Do mesmo modo, a recepção positiva do livro de Fernando Gabeira não deve ter sido motivada apenas pela suposta versão conciliadora que ele possa conter (o que é discutível). Aliás, para citar novamente Eric Hobsbawm, disse o historiador marxista inglês que muitos dos debates mais ideológicos que travamos "referem-se a questões sobre as quais os nãohistoriadores menos sabem e se importam" (HOBSBAWM, 1998, p. 285). Enfim, há qualidades evidentes na narrativa de $O$ que é isso, companheiro?, além da grande curiosidade que o tema despertava. Outras memórias - ao contrário do que Daniel afirma - tiveram também calorosa acolhida, como o best-seller Os carbonários, de Alfedo Sirkis, cuja influência pode ser medida pelo fato de o autor ter cedido os direitos de uso de algumas passagens à Rede Globo para a produção da série Anos Rebeldes (SIRKIS, 1998, 31). A prevalência da mencionada memória confortável, segundo Denise Rollemberg que concorda sobre Gabeira com Daniel Aarão - teria sido capaz de condenar ao esquecimento "dezenas de memórias", inclusive as militares, "que perderam a batalha da imagem" (ROLLEMBERG, 2003, p. 76), algo que caberia qualificar melhor já que não se sabe que memórias são essas e, no que diz respeito aos militares, eles sempre são bem avaliados em pesquisas de opinião. Por fim, há a questão do silêncio, comum em situações desse tipo, fases conhecidas como suspensão ou latência e sobre as quais já tratei em outro trabalho (FICO, 2013).

Algumas das principais premissas de Daniel Aarão são imprecisas e carentes de evidências empíricas. Por exemplo, ele diz que "grande parte da sociedade brasileira preferiu demonizar a ditadura (...)”, que “(...) para a elaboração da conciliação nacional e de um pacto democrático, tendeu a predominar a versão de que a sociedade brasileira apenas suportara a ditadura (...)" e que “(...) muitos se confortaram com raciocínios polarizados" (REIS, 2014, p. 7). A ausência de comprovações e a imprecisão de expressões 
como "grande parte" e "tendeu a predominar" - assim como a generalização contida na expressão "a sociedade" - tornam os enunciados metodologicamente inseguros, apesar do tom apodíctico. Não sabemos que partes da sociedade demonizaram (provavelmente tendo antes apoiado) a ditadura.

Entretanto, essas minhas ressalvas não tocam o ponto principal: a história da ditadura militar tem sido vista como a história do confronto entre repressão política e "luta armada". Esse combate se tornou o fato emblemático do período, tendo constituído memória, imaginário, iconografia, filmografia etc. que atribui às ações armadas urbanas, à chamada guerrilha do Araguaia e à repressão a ambas importância histórica desmedida. Não haverá evento sobre a ditadura militar no qual não se vejam fotos das manifestações estudantis de 1968, frequentemente confundidas com as ações armadas. Aliás, uma digressão: graças ao investimento que o Correio da Manhã fez no seu fotojornalismo desde 1964, temos excelente registro visual das manifestações estudantis de 1966 a 1968. O trabalho do Correio de Manhã - cujos fotógrafos se aproximaram dos estudantes - estimulou o Jornal do Brasil. Destacaram-se os fotógrafos Rubens Seixas e Alberto França, do Correio da Manhã, e Evandro Teixeira e Alberto Jacó, do Jornal do Brasil (OLIVEIRA, 1998). Como essas são as únicas imagens que temos da repressão, elas, muitas vezes, são difusamente percebidas como imagens das ações armadas.

Enfim, a transformação do confronto entre "luta armada" e repressão em fato emblemático há de ter sido motivada pela violência e pela dimensão traumática dos episódios em pauta. Mas, como já disse - perdoe o leitor a repetição - a história do Brasil no período não pode ser reduzida à história da ditadura militar. Quando coloco a expressão "luta armada" entre aspas não estou desqualificando a esquerda que optou por aquelas ações violentas, mas ressalvando que tal processo foi bastante inexpressivo no Brasil. Ainda que tenham tido consequências dramáticas para os envolvidos e para o próprio processo de saída da ditadura - como ainda veremos -, as ações armadas foram poucas e sua fase verdadeiramente ofensiva ou revolucionária muitíssimo breve porque, diante da óbvia superioridade e truculência da repressão, elas se tornaram meramente defensivas. O que há de relevante na discussão levantada por Daniel não é propriamente a memória confortável que ele identifica, mas o fato de que a historiografia persiste em 
caracterizar as ações armadas como fato emblemático da história da ditadura. A questão insistentemente levantada por Daniel Aarão Reis Filho, além dos demais problemas apontados, reforça essa perspectiva e deixa de lado, como sujeito anódino da história, as “maiorias conservadoras (...) que se imobilizaram” (REIS; ROLLAND, 2008, p. 13), as "grandes maiorias conservadoras, resignadas, ensimesmadas, [que] sequer estavam na janela, e nem viram o ano [de 1968] passar (REIS, 2008, p. 17).

\section{3) Tabu}

Após as conhecidas manifestações de 1968, lideradas pelos estudantes universitários e secundaristas, o ano terminou - ao contrário do que supõe Zuenir Ventura - e terminou mal, com a decretação do Ato Institucional n ${ }^{\circ}$, em 13 de dezembro de $1968 .{ }^{29}$ Após o Al-5, esses estudantes, seguramente frustrados com o que aconteceu, se tornaram facilmente recrutáveis pelas organizações que se autodenominavam revolucionárias. Tais jovens abandonaram família e amigos, passaram a viver isolados, em moradias temporárias, com nomes falsos, sob rotinas exigentes impostas pelas organizações para mantê-los sob "tensão máxima"30 e, mesmo sem treinamento adequado, participaram eventualmente de ações armadas e/ou de atividades de risco que envolviam a preparação de tais ações. Muitos foram presos e torturados; alguns foram mortos. $\mathrm{O}$ ingresso desses rapazes e moças nas mencionadas organizações seguramente deveu-se a motivações mais imediatas do que as que levaram os quadros dirigentes e militantes mais antigos a optarem, antes do Al-5, pela "luta armada". Esse é um dos temas tabus que persistem intocados pela historiografia sobre a ditadura militar. Trata-se de tópico delicado porque chama atenção para o fato de que os dirigentes das organizações que se diziam revolucionárias estavam em condições de antever os resultados trágicos do recrutamento de jovens inexperientes.

Em seu aclamado trabalho sobre o movimento estudantil, publicado em 1987, João Roberto Martins Filho lembrou a atração que o livreto de Jules Régis Debray, Révolution

\footnotetext{
${ }^{29}$ Para descrição dos eventos daquele ano, ver Fico (2009).

${ }^{30}$ Para descrição da sobrecarga de tarefas e tensão de toda ordem a que os militantes estavam submetidos, ver Reis Filho (1980, p. 118 e seguintes).
} 
poderio, mostrando-se capazes de conseguir dinheiro e fazer incursões ousadas, além de usarem jargão militar que parecia lhes dar capacidade de se ombrear com os verdadeiros militares. Mesmo muitos anos depois, após o ritual das autocríticas, Franklin Martins ainda falava em "ações militares". ${ }^{11}$ Também pode ter desempenhado algum papel de atração dos jovens estudantes a pouco disfarçada insatisfação com os velhos políticos que, segundo Franklin Martins,

haviam sido derrotados em 64 sem esboçar qualquer resistência. Prometeram ao povo uma vida nova, mas, na hora $\mathrm{H}$, deixaram o povo sozinho. Refugiaram-se nas embaixadas, caíram na clandestinidade, preferiram aguardar tempos mais amenos. No mínimo, haviam se revelado ingênuos e despreparados. Por que os jovens, então, deveriam levar em conta seus conselhos? (MARTINS, 2002, p. 45)

Vladimir Palmeira - que teve impressionante atuação como líder estudantil -, quando falou vinte anos depois sobre 1968, lembrou a imprudência da opção feita pelos estudantes. Disse ele que, então, se começou "a preparar um plano de luta armada, um plano revolucionário, um plano de qualquer coisa, era tudo mesmo uma abstração. O Al-5 iria dar uma grande força a isso". Perguntado sobre o magnetismo, a capacidade de atração das organizações que se diziam revolucionárias, ele respondeu:

Você tinha toda uma fração politizada [ou seja, grupos de estudantes mais politizados integrantes das manifestações de 1968], participando de enfrentamentos. De repente [com o Al-5], não há mais possibilidades de luta institucional [manifestações, passeatas] e, ao mesmo tempo, você tem um chamamento [da parte das organizações ditas revolucionárias] para a ação [armada], e a realização de ações vitoriosas, porque a polícia levou algum tempo para se adequar e poder começar a golpear essas organizações. Mas a essa altura centenas de estudantes já haviam ingressado nos quadros das ações armadas. (PALMEIRA, 2008, p. 124)

Em sua tese já mencionada, Marcelo Ridenti contabilizou, com base em dados do

${ }^{31}$ Citado por Martins Filho (1987, p. 197). Tais ações nada tinham de militares, apenas envolviam armas e violência. $O$ treinamento em Cuba também era precário como se vê em Rollemberg (2001). 
Filho situou o movimento estudantil como "peão num jogo mais complicado - o da revolução. Como, no entanto, era o [movimento social] mais ativo e articulado, era ali que se recrutavam militantes e dirigentes para os partidos revolucionários" (REIS FILHO, 1998, p. 32).

Em seu livro de memórias, publicado em 1982, Herbert Daniel, ex-militante da Vanguarda Popular Revolucionária (VPR), diz que pegou em armas sem saber o que fazer com elas. Alguém mais experiente da organização lhe disse que, se fosse preciso atirar, bastava apontar e apertar o gatilho: “Esta foi a mais completa e mesmo única instrução militar que tive durante os meus primeiros tempos de guerrilha" (DANIEL, 1982, p. 17). Em sua tese, Marcelo Ridenti comentou a repressão sobre as organizações e as dificuldades que enfrentaram para sobreviver, até mesmo em termos de quadros, o que as obrigava "a recorrer às últimas reservas humanas de que dispunham para combater a ditadura: os seus simpatizantes, sobretudo do meio estudantil, politizados nos movimentos sociais de 1967 e 1968". Nesse contexto, Marcelo citou depoimento de Vinícius Caldeira Brant, expresidente da UNE e ex-militante da Ação Popular (AP) e do Partido Revolucionário dos Trabalhadores (PRT), que foi preso com 29 anos:

De repente, eu me vi numa cela no DOI-CODI em 1970; nas outras celas, tinha um bando de meninos ... [a esquerda] estava sendo dizimada e pessoas que eram, até então, meras simpatizantes da resistência iam-se incorporando àquilo, correndo riscos; às vezes, eram pessoas que nem estavam preparadas. (Citado por RIDENTI, 1993, p. 253)

Quando mencionei o caráter inexpressivo da "luta armada" no Brasil - não obstante ela tenha se tornado o fato emblemático da história da ditadura - ressalvei o óbvio impacto que tal experiência teve na vida dos militantes em geral. Particularmente, a prisão, a tortura e a morte desses rapazes e moças tornaram a fase final do processo um evento traumático. Não me refiro apenas ao impacto individual que tal coisa possa ter causado nos militantes sobreviventes - que não costumam elaborar a questão em seus 
atenção dos pesquisadores. A inserção dessa temática na história dos eventos traumáticos do século XX, especialidade muito discutida internacionalmente, ${ }^{32}$ talvez seja vista com menosprezo no Brasil porquanto aqui prevalece forte tradição analítica marcada pela tese otimista de Gilberto Freyre sobre a singularidade do brasileiro e pela não menos conhecida interpretação pessimista de Roberto DaMatta segundo a qual tal singularidade seria marcada por um "personalismo pré-moderno", como já vimos (SOUZA, 2015, p. 70). ${ }^{33}$ Se essas teses de Freyre e DaMatta, segundo penso, são muito questionáveis nas suas versões originais, a recepção rarefeita que a sociedade delas faz e leva a noções muito consagradas sobre singularidade, esperteza, jeitinho brasileiro e quejandos -, essa chega a grau de cinismo. ${ }^{34}$ Mas são amplamente aceitas, como disse, tanto as teses quanto a recepção rarefeita. Talvez seja essa predisposição favorável que explique o predomínio, na literatura especializada, das figuras do paradoxo e da ironia, conforme já mencionei. Seríamos absurdos e ridículos: dizê-lo entretém o público leitor. Daí a dificuldade de considerar seriamente a questão do trauma; daí a suposta dificuldade de entendimento do país, salvo para os profissionais do ramo.

A força dessas interpretações não deve intimidar os poucos que as vemos criticamente como grave prejuízo para a historiografia - direi apenas assim para não ser grandiloquente. Apesar do predomínio das leituras marcadas pela contradição e ironia, é preciso deslindar a questão do trauma como problema historiográfico porque ele terá sido, provavelmente, a causa da construção do confronto entre "luta armada" e repressão como fato emblemático da ditadura, apesar de as ações armadas terem sido em pequeno número, restritas geograficamente (basicamente às cidades do Rio de

\footnotetext{
${ }^{32}$ Consultar, a propósito, LaCapra (2001).

33 Sobre a alternância de leituras otimistas e pessimistas sobre “o brasileiro", ver Fico (1997, p. 27 e seguintes.)

${ }^{34}$ Sempre recusei a leitura de que a sociedade brasileira viveria uma espécie de "comunhão numa barbárie alegre e carnavalizada”. A passagem em que, na minha tese de doutorado, faço essa crítica a DaMatta, curiosamente não aparece no livro que a publica. Não me recordo como isso aconteceu. A tese tem o mesmo título que o livro, foi defendida no Programa de Pós-graduação em História Social da Universidade de São Paulo, em 1996, e a passagem suprimida no livro está nas páginas 67-68 da tese.
} 
Janeiro e de São Paulo) e limitadas temporalmente (avolumaram-se em 1969 e quase não ocorreram em 1971). A hipótese de que a construção desse fato emblemático decorreu de trauma causado pela violência mencionada, demanda, naturalmente, pesquisa sofisticada. Não se trataria, por certo, de memória traumática nos moldes da que se constituiu na Argentina, mas, como já aventei em outro trabalho, de memória restrita aos grupos de esquerda e marcada também pela frustração: frustração com o fracasso da opção pelas armas; com a imutabilidade do projeto militar de transição; com a ausência de clara ruptura entre ditadura e democracia e com a falta de punição dos torturadores (FICO, 2013).

Essa hipótese também parece plausível por outra razão: os depoimentos de exmilitantes sobre a persistência das atividades das organizações que optaram pelas ações armadas, mesmo depois que se tornou evidente a sua inviabilidade, indicam que havia consciência sobre tal obstinação. Parece ter havido rápida percepção da inutilidade das ações armadas urbanas após o sucesso da repressão, mas, ao mesmo tempo, em paralelo, terá havido também a decisão inercial de continuar com elas, uma predisposição de algum modo autodestrutiva. Isso provavelmente terá ocorrido já a partir do final de 1969 e início de 1970, sendo a morte do líder da Ação Libertadora Nacional (ALN), Carlos Marighella, em novembro de 1969, um marco evidente. O sequestro do embaixador norte-americano, Charles Elbrick (agosto de 1969) e a fortíssima repressão desencadeada em seguida, funcionaram, quase catatonicamente, como estímulo ofensivo e repto defensivo. $O$ autor que melhor se aproximou da análise do fenômeno da autodestruição, embora sem considerar a dimensão traumática que menciono, foi Marcelo Ridenti, que dedica as últimas páginas de sua tese ao delicado tema (RIDENTI, 1993, p. 266 e seguintes).

A atitude de alguma maneira inercial e suicida dos militantes, por não ser banal, também deve ter deixado consequências na memória que os sobreviventes construíram sobre o período: a comprovação dessa outra hipótese também demandaria pesquisa complexa. De fato, se essas hipóteses - sobre o impacto, nos sobreviventes, da violência contra jovens inexperientes e da inútil persistência da "luta armada" na fase que os próprios ex-militantes chamam de sobrevivência - estiverem corretas, talvez possamos 
compreender melhor a gênese do fato emblemático e da memória confortável sobre a chamada "luta armada": eles não seriam decorrência de fatos discretos como o livro de Fernando Gabeira ou os interesses pecuniários envolvidos no processo da anistia, mas teriam fundo traumático: líderes e quadros organizados mais experientes sofreram, foram presos, torturados e morreram; mas, como se não bastasse, jovens simpatizantes inexperientes também o foram.

Além dessa dimensão traumática marcada por grave conflito de natureza éticomoral, a distinção entre lideranças, quadros organizados e simpatizantes é importante por outra razão. O recrutamento fácil de estudantes secundaristas e universitários frustrados com o Al-5 após as expectativas criadas com as manifestações de 1968 e siderados pela fortaleza que as organizações que se acreditavam revolucionárias artificialmente ostentavam - situa questão historiográfica que mencionei em trabalhos anteriores: não havia relação de causalidade entre a repressão e a "luta armada", apesar das afirmações em contrário dos remanescentes de ambas e de alguns analistas (FICO, 2001, p. 63-64; FICO, 2008, p. 199). ${ }^{35}$ A esquerda não optou pelas ações armadas por causa do Al-5. Entretanto, isso diz respeito aos que ingressaram nas organizações por motivações, digamos assim, ideológicas, antes do Al-5: os simpatizantes foram levados às organizações pela conjuntura de desesperança ocasionada pelo ato, além dos outros motivos que apontei.

Não é justo nem adequado, em termos epistemológicos, o uso de hipóteses “contrafactuais": se já é difícil explicar o porquê de a chamada esquerda revolucionária ter optado pelas armas e ter persistido com as ações armadas urbanas mesmo diante da evidência de sua fragilidade em face da repressão, é impossível especular sobre o que teria acontecido se as organizações tivessem desistido antes de serem aniquiladas. Ainda assim, essa é uma questão histórica importante porque não se tem sublinhado devidamente a importância do mecanismo de retroalimentação. "Luta armada" e repressão não tinham relação de causalidade, mas se retroalimentavam na medida em que a esquerda justificava sua opção com o endurecimento do regime, e a chamada linha dura justificava a repressão com as ações armadas.

\footnotetext{
${ }^{35}$ Fernando Henrique Cardoso disse que o Al-5 veio em consequência das manifestações de 1968, das ações armadas, da resistência democrática e da pressão interna da linha dura (CARDOSO, 1972, p. 77).
} 
O tema, entretanto, não deve ser tratado segundo ótica reducionista, isto é, a identificação de suposta culpa pelo incremento da repressão ou o debate pueril sobre quem começou primeiro. A especulação "contrafactual” aqui é importante porque, se as organizações tivessem interrompido as ações armadas, bem sabemos que os agentes da repressão buscariam outras vítimas, pois foi assim que eles agiram quando derrotaram a "luta armada" no início dos anos 1970 (foram atrás dos comunistas não adeptos da violência). É por isso que não podemos estabelecer a relação de causalidade: as comunidades de segurança e de informações foram criadas e se mantiveram independentemente da existência das organizações ditas revolucionárias. Entretanto, se as organizações interrompessem as ações armadas, está claro que o processo de retroalimentação cessaria pela simples ausência de um dos polos, fragilizando precocemente os órgãos de informações e de segurança, de modo que não é abusivo dizer-se que a chamada luta armada retardou o fim da ditadura.

De fato, aquilo que se chama de radicalização das manifestações do final dos anos 1960, no Brasil, corresponde à estratégia das esquerdas ditas revolucionárias de utilizarem a insatisfação dos estudantes com as condições de ensino, de alimentação, entre outros problemas típicos que os mobilizavam, como forma de congregá-los para a luta revolucionária. Segundo João Roberto Martins Filho, "a direção do movimento estudantil tinha chegado, em meados de 1967, à proposta de acirramento das lutas populares, visando a derrubada da ditadura e a instauração de um governo popular". Ações estudantis em 1968 tinham traços "semiguerrilheiros", mas houve protestos radicalizados dos estudantes desde 1966 (MARTINS FILHO, 1987, p. 176 e 185).

Todos esses protestos foram considerados para a implantação do aparato de repressão política. Havia avaliação muito objetiva quanto aos prejuízos que os protestos traziam, não apenas em termos políticos. Quinze dias depois da Passeata dos Cem Mil, Costa e Silva reuniu o Conselho de Segurança Nacional para ouvir de seus membros se deveria decretar novo ato institucional. Durante a reunião, o ministro da Fazenda, Antônio Delfim Netto, disse que as manifestações haviam gerado prejuízo da ordem de NCr\$ 43 milhões, pois estava prevista a arrecadação de NCr\$ 168 milhões e foram arrecadados apenas NCr\$ 125 milhões, isso no mês de junho, quando ocorreram as 
Do ponto de vista político, o chefe do Serviço Nacional de Informações (SNI) - o futuro presidente Emílio Garrastazu Médici - informou o conselho de que as manifestações tinham procedimentos que consistiam, primeiro, na disseminação de propaganda que apresentava o governo como ditatorial e submisso aos interesses imperialistas norte-americanos e, a partir da utilização das "justas reivindicações" estudantis, utilizavam a massa, “dinamizada sob pretextos aceitáveis”, para desmoralizar a polícia, “partir para a subversão generalizada e desencadear a guerra civil”. Para Médici, o estágio em que a ofensiva da esquerda se encontrava era avançado:

No momento, o que se vê nas ruas não é mais a condução de legítimas reivindicações estudantis, mas um movimento que tem um objetivo nítido, qual seja, o de derrubar o governo revolucionário (...) para posterior implantação da revolução socialista brasileira (...) Já não resta a menor dúvida de que os movimentos de falsos estudantes (...) representam a contrarevolução. ${ }^{37}$

Médici mencionou assaltos a bancos, roubo de armas e explosivos e "utilização de estudantes como massa de manobra" como partes do plano da esquerda para a tomada do poder. Ele era favorável à imediata decretação de novo ato institucional, mas seguiu a orientação de Costa e Silva de usar apenas a polícia. Como se sabe, nos anos seguintes, durante seu mandato na Presidência da República, Médici ordenaria combate sem tréguas às ações armadas. Em 1982, durante rara entrevista, disse que esse confronto "foi uma guerra que aceitamos" e se vangloriou: “Eu acabei com o terrorismo neste país. Se não aceitássemos a guerra, se não agíssemos drasticamente, até hoje teríamos o terrorismo" (SCARTEZINI, 1985, p. 36). Também para Médici - segundo a memória que construiu - o confronto entre repressão e "luta armada" foi o fato emblemático da ditadura.

\footnotetext{
${ }^{36}$ Arquivo Nacional. Ata da $41^{\text {a }}$ sessão do Conselho de Segurança Nacional, de 11 de julho de 1968. Livro 4, fl. 33.

37 Idem. fls. 12 e 13.
} 
A reunião de 11 de julho de 1968 do Conselho de Segurança Nacional foi tão ou mais importante do que a de 13 de dezembro de 1968, que homologou a decisão de Costa e Silva de decretar o Al-5. Digo isso porque, em julho, ficou patente o processo de retroalimentação a que me referi. Mais do que simples pretexto para o endurecimento do regime, a radicalização da esquerda ocasionou genuína preocupação em alguns setores da sociedade, como nos empresários paulistas preocupados com os assaltos a bancos (e que, por isso mesmo, financiaram a OBAN) e em setores das classes médias, inclusive aqueles que estabeleceram empatia inicial com os estudantes que faziam reivindicações por mais verbas e de natureza assistencial e/ou que foram vítimas de repressão desmedida. Essa avaliação não foi um ardil, nem simples pretexto para endurecimento do regime, até porque da reunião não derivou imediatamente nenhum ato institucional. É nesse sentido que chamo a preocupação de genuína, na medida em que expressava temores efetivos: o medo de militares, empresários e outros setores de que as manifestações desbordassem do campo político-institucional e se tornassem tumultuárias ou revolucionárias, como pensava Médici. Justamente porque o Al-5 não foi decretado em meados de 1968, e porque a esquerda dita revolucionária e o movimento estudantil mesclado a ela não cessaram as atividades que podiam ser caracterizadas como radicais, é que se pode falar em retroalimentação. Tal interação deu-se exatamente nesse período, no qual os principais atores já sabiam o que estava em jogo.

Ora, os setores favoráveis à imediata reabertura da temporada de punições, representados no Conselho de Segurança Nacional, entre outros, pelo ministro da Justiça (que, desse modo, evitava que os ministros militares se contrapusessem à conhecida diretriz de Costa e Silva de não editar um ato institucional), não descansariam até que obtivessem o que desejavam, desde que o Al-2 teve seu prazo de validade encerrado em 15 de março de 1967. Desse modo, a chamada linha dura, diante do recuo dos protestos estudantis, promoveu, depois da reunião de 11 de julho de 1968, uma série de atos de provocação e atentados (que não ocorreram antes) a fim de perpetuar clima de agitação que permitisse arrancar de Costa e Silva novo ato institucional. Basta simples consulta à cronologia para se verificar que, até a Passeata dos Cem Mil, no dia 26 de junho de 1968, houve apenas manifestações sociais sob a liderança dos estudantes. Depois da reunião do 
Conselho, no dia 11 de julho, houve a depredação do teatro onde se encenava Roda Viva (17/7), o atentado à bomba contra a $A B I$ (22/7), a invasão da Universidade de Brasília (29/8), a invasão da Universidade Federal de Minas Gerais (29/9), a invasão da Universidade de São Paulo (2/10), o sequestro e espancamento da atriz Norma Benguell (8/10), isso sem falar na abortada tentativa de se utilizar uma unidade de paraquedistas das Forças Aéreas para eliminar oposicionistas e fazer atentados à bomba (denunciada em outubro). Todos esses episódios foram provocados pela chamada linha dura. Tais provocações, e a escalada de pressões feitas pelos ministros militares contra Costa e Silva a partir dos discursos de Márcio Moreira Alves, levaram ao Al-5, que o marechal foi obrigado a assinar.

Essas provocações e atentados eram os recursos utilizados pelos setores mais brutalizados do regime para pressionar os generais-presidentes a partir de 1968. Trata-se de padrão ainda não devidamente assinalado pela literatura. Costa e Silva, por exemplo, sabia que esses episódios eram promovidos pela direita radical militar e civil. Isso também aconteceu com Geisel (assassinatos de Herzog, de Fiel Filho e bombas na $A B I$ e $O A B$ ) e Figueiredo (vários atentados em 1980 e Riocentro em 1981). Costa e Silva, entretanto, não resistiu à demonstração de força da direita terrorista.

\section{4) Nomes e datas}

Daniel Aarão Reis Filho tem insistido em chamar o golpe e a ditadura de "civilmilitar" sustentando que a expressão "ditadura militar" foi usada pelos opositores do regime apenas para tentar fragilizar seus principais representantes (REIS FILHO, 2015, p. 237). A oposição ao regime tudo teria feito para caracterizar a ditadura como militar. Entretanto, quando consultamos os documentos das organizações da esquerda dita revolucionária, vemos que elas realmente chamavam o regime de ditadura, muitas vezes de ditadura militar, frequentemente apenas ditadura, também ocorrendo "ditadura de Castelo Branco", caracterização dada pelo Partido Comunista do Brasil (PC do B); “ditadura de fato" e "ditadura de classe”, pela Organização Revolucionária Marxista Política Operária (ORM-POLOP); “ditadura contra-revolucionária” e "ditadura militar 
neocolonialista”, pelo Partido Comunista do Brasil - Ala Vermelha; “regime forte”, pelo Comando de Libertação Nacional (COLINA); "aparelho burocrático-militar”, "ditadura reacionária” e "ditadura militar, expressão do poder burgês-latinfundiário”, pelo Partido Comunista Brasileiro Revolucionário; “ditadura das classes exploradoras", pela Vanguarda Armada Revolucionária Palmares (VAR-Palmares); apenas ditadura ou regime e "golpe de Estado de 1964" (e não "golpe militar”), pelo Movimento Revolucionário 8 de Outubro-Dissidência Comunista da Guanabara (MR-8/DI-GB), entre outras ocorrências (REIS; SÁ, 2006). Na resolução de maio de 1965, o PCB usou “ditadura reacionária e entreguista". A variedade de usos fragiliza o argumento de Daniel dando a impressão de que se trata de elaboração ex post facto.

A denominação civil-militar seria razoável, segundo Daniel, por causa do apoio civil que o golpe e a ditadura tiveram, o que constituiria a "dimensão civil do regime ditatorial, mesmo que o topo da pirâmide do poder fosse ocupado por chefes militares" (REIS, 2014, p. 62. Grifado no original). Entretanto, virtualmente, tudo em política pode ser analisado segundo a rede de apoios e adversidades em que se insere, de modo que dizer que algo recebeu o apoio de outrem não retira a essencialidade de algo, sua configuração imanente. Por exemplo, o Estado Novo pode ser caracterizado como ditadura civil tutelada pelos militares: o golpe de 1937 teria sido militar, mas com roupagem civil, como disse Aspásia Camargo. Getúlio Vargas teria conseguido usar e conter os militares, segundo José Murilo de Carvalho. ${ }^{38} \mathrm{O}$ apoio dos militares - nesse caso absolutamente decisivo - não retira a natureza civil daquele regime.

Por outro lado, o qualificativo civil diz pouco quando usado apenas em oposição a militar. Nesse sentido - conforme já foi apontado por Demian Melo -, o uso de civil feito por Dreifuss (com conotação de classista, empresarial) foi mais preciso (MELO, 2014, p. 168). Ademais, fosse razoável o argumento de Daniel, teríamos de designar a ditadura como civil-militar-empresarial-midiática-católica e assim por diante, tornando o debate ainda mais viciado por nominalismo.

Há relativa variedade de usos: Eliézer Rizzo de Oliveira falou em "movimento

\footnotetext{
${ }^{38}$ Para consideração dessas questões, inclusive dos autores mencionados, queira ver Fico (2011).
} 
político-militar" em seu livro de 1976; Marcelo Ridenti, em 1993, já usava a expressão "golpe civil-militar", antes do posicionamento mais insistente de Daniel, e adotou “regime civil-militar" em publicação de 2003; João Roberto Martins Filho preferiu "golpe político-militar" no livro clássico de 1987; a historiadora marxista Virgínia Fontes reforça a opção de Dreifuss com a expressão “ditadura empresarial-militar” e alguns autores preferem deixar como está, chamando a ditadura de militar. ${ }^{39}$

O golpe foi efetivamente dado (não apenas apoiado) por civis e militares e, portanto, é possível chamá-lo de civil-militar. Alguns passos subsequentes foram marcando o caráter militar do novo regime, principalmente a decisão do Comando Supremo da Revolução de abortar, com o primeiro ato institucional, a discussão que havia no Congresso Nacional sobre conceder ou não aos vitoriosos poderes de cassação de parlamentares e, depois, a prorrogação do mandato de Castelo Branco até 15 de março de 1967 (decisão tomada em julho de 1964). O regime subsequente foi inteiramente controlado pelos militares, de modo que adjetivá-lo em ressalva ("foi militar, mas também civil" ou empresarial ou o que seja) é supérfluo e impreciso - além de ter, como tudo mais em História do Tempo Presente, imediata implicação política: nesse caso, justamente por causa dessa adversatividade, a conotação é de redução da responsabilidade dos militares.

Essa questão ganha maior densidade e interesse quando associada às propostas de periodização da ditadura sustentadas por Daniel Aarão Reis Filho e Marco Antonio Villa. Villa considera que só se pode falar em ditadura durante o período de vigência do Al5 , mesmo assim com ressalvas. ${ }^{40}$ Nesse período, "o Executivo teve plenos poderes e os exerceu de forma ditatorial" - definição que é tautológica e irresoluta (VILLA, 2014, p. 370). Ele sustenta que não se pode falar em ditadura no período 1964-1968 "no sentido da etimologia política desse conceito", mas não faz um estudo da origem e evolução da palavra ditadura. Para Villa, o período que vai do golpe até a decretação do Al-5 não foi uma ditadura porque o Congresso Nacional e outras casas legislativas estiveram abertos, houve eleições para governadores e prefeitos (exceto nas capitais e cidades declaradas como áreas de segurança nacional), houve liberdade de imprensa e de editoração, bem

\footnotetext{
39 Ver Oliveira (1976, p. 47); Ridenti (1993, p. 27); Ridenti (2003, p. 152); Martins Filho (1987, p. 75); Fontes (2014, p. 11); Codato (2004, p. 12); Napolitano (2016 p. 11).

${ }^{40}$ As ressalvas dizem respeito ao fato de que houve eleições entre 1968 e 1978. Villa (2014, p. 373).
} 
como intensa atividade cultural (cinema, música e teatro), além do movimento estudantil.

Seria possível mostrar que cada um desses aspectos assinalados por Villa é discutível porque, entre 1964 e 1968, houve tremendas restrições ao funcionamento do Congresso Nacional (inclusive o seu fechamento) e outras casas legislativas, gravíssimas limitações no tocante às eleições, censura da imprensa, do teatro, do cinema e dos livros, além de repressão brutal contra o movimento estudantil. Mas isso implicaria aborrecer o leitor com listas de exemplos e não iria ao ponto central: se retirarmos o que é tautológico da definição de Villa, resta que houve ditadura quando "o Executivo teve plenos poderes". Ora, podemos observar que, no período em pauta (31 de março de 1964 a 13 de dezembro de 1968), o Executivo teve plenos poderes durante a vigência do Ato Institucional e do Ato Institucional n. 2. Como se sabe, o primeiro ato - depois conhecido como Al-1 - permitiu que o Comando Supremo da Revolução, primeiro, e o presidente Castelo Branco, depois, cassasse mandatos e suspendesse direitos políticos até 15 de junho de 1964. Desse modo, da decretação do primeiro ato ( 9 de abril de 1964) até essa data terá havido ditadura - poder-se-ia pensar seguindo a linha de raciocínio de Villa. Esse prazo de 15 de junho foi limitação que os golpistas vitoriosos se impuseram apenas em relação a essas duas específicas punições (cassações de mandatos e suspensões de direitos políticos), mas o ato estabeleceu que outra punição, a possibilidade de demitir, aposentar compulsoriamente, transferir ou reformar funcionários públicos e militares, prevaleceria até outubro de 1964. Seria o caso de decidirmos se isso configura "plenos poderes" e estendermos ou não a ditadura até outubro. $\mathrm{O}$ ato como um todo (notem que os militares se preocupavam muito com prazos) vigoraria até o dia da posse do presidente que sucederia o mandato inicialmente exercido por Jânio Quadros, continuado por João Goulart, arrebatado pelo golpe momentaneamente para o presidente da Câmara, Ranieri Mazzili, e que seria, afinal, concluído pelo marechal Castelo Branco. Ou seja, quando da decretação do Ato Institucional, ainda não havia o entendimento de que os militares persistiriam controlando a situação por anos e anos: o ato previa eleições normalmente em 3 de outubro de 1965 e posse do novo presidente em 31 de janeiro de 1966, data em que também deixaria de vigorar como um todo. Desse modo, as principais punições vigoravam até junho de 1964; a possibilidade de demissão 
de funcionários públicos e passagem para a reserva de militares até outubro de 1964 e as demais prerrogativas estabelecidas pelo ato até janeiro de 1966. Essas prerrogativas que permaneceriam até 1966 davam maior poder ao presidente da República e ao Executivo, facilitando a decretação do Estado de Sítio, permitindo a aprovação de leis por decurso de prazo e a aprovação de emendas constitucionais por maioria absoluta - mas tudo isso talvez não possa ser considerado "plenos poderes".

É indispensável dar atenção a esses detalhes porque nada disso, evidentemente, foi feito de maneira impensada, já que se tratava, nada mais, nada menos, do arcabouço institucional da "revolução vitoriosa". Por que os prazos diferentes? Por que a evidente hierarquização das punições? Por que os poderes ampliados do Estado de Sítio e a imposição do decurso de prazo? Juntamente com a facilitação da aprovação das mudanças constitucionais, essas últimas prerrogativas eram o terceiro nível da cronologia de excepcionalidades: por quê? Voltarei ao tema do arcabouço institucional na conclusão deste artigo - que prometo para breve -, mas surpreende que a maioria da literatura especializada não atribua qualquer importância a nada disso, tampouco Villa e Daniel que propõem as novas periodizações. Ora, em se tratando de propor periodizações, o estudo acurado da cronologia é etapa preliminar essencial.

Em 22 de julho de 1964, como já lembrado, o Congresso Nacional aprovou a prorrogação do mandato de Castelo Branco até 15 de março de 1967, rompendo, portanto, com a juridicidade estabelecida pelo Ato Institucional. Por se tratar de medida aprovada pelo parlamento, talvez não se possa falar em ação inteiramente autoritária, embora o Congresso estivesse expurgado em função das cassações.

No ano seguinte, houve novo "surto revolucionário" com o Al-2, que reabriu a temporada de punições em 27 de outubro de 1965, conferindo novamente a Castelo Branco poderes para cassar mandatos eletivos e suspender direitos políticos (justamente as excepcionalidades mais importantes) até 15 de março de 1967, entre outros dispositivos. Não parece indevido caracterizar tais poderes como plenos: o presidente da República podia suspender os direitos políticos de qualquer cidadão.

Se for assim, segundo a própria definição de Villa teria havido ditadura entre o 
golpe e junho (ou outubro) de 1964. Depois, novamente, entre 27 de outubro de 1965 e o fim do mandato de Castelo em 15 de março de 1967. Finalmente, o país entraria em ditadura depois de 13 de dezembro de 1968 com o Al-5. Tentando entender a proposta de Villa (de que não houve ditadura na etapa inicial), talvez devêssemos supor que, para ele, nos primeiros anos houve, digamos, espasmos ditatoriais, algo que não caracterizaria própria e permanentemente uma ditadura, razão pela qual Villa também apela para a ironia e para a chave da singularidade do Brasil: seria uma ditadura à brasileira, título do seu livro.

Quem discordaria de Villa, se vivo estivesse, seria o marechal Costa e Silva: na continuação da reunião do Conselho de Segurança Nacional de 11 de julho de 1968, já no dia 16, tentando justificar porque não desejava novo ato institucional naquele momento, o marechal abriu-se com seus ministros, em tom de desabafo confessional: "devo dizerIhes, fruto de uma convicção sincera, decorrente ela de alguns dias de ditador neste país, que a ditadura jamais será uma solução para o Brasil”. Ou seja, Costa e Silva não tinha dúvida de que havia sido um ditador. ${ }^{41}$

Daniel Aarão se detém pouco na consideração dos primeiros momentos após o golpe quando trata da periodização porque se preocupa mais com o fim da ditadura, mas menciona a cronologia básica após o Ato Institucional. Ele não se questiona sobre os prazos diferenciados para as punições e entende que "a data-limite funcionou como uma espécie de compromisso com a restauração da democracia”. Entretanto, ele se confunde com o prazo limite, pois faz afirmação imprecisa sobre o poder de efetuar cassações e suspensões de direitos políticos. ${ }^{42}$

Quando mais se aproxima do que poderia ser uma definição conceitual de periodização, Daniel dá indicações bastante frágeis sobre a questão misturando periodização e cronologia: "referências cronológicas não são objetivas, não estão lá, antes que a história se faça, determinando seus caminhos (...) A cronologia (...) tende a ordenar a reflexão histórica, condicionando-a em diferentes direções, segundo escolhas bem

\footnotetext{
${ }^{41}$ Arquivo Nacional. Ata da continuação da $41^{a}$ sessão de 11 de julho de 1968 do Conselho de Segurança Nacional, em 16 de julho de 1968. Livro 4, fl. 29.

${ }^{42}$ Daniel indica como data limite o dia 31 de janeiro de 1966. (REIS, 2014, p. 52).
} 

seja lá quando for, tudo ficará muito difícil para o historiador. Isso nada tem a ver com o estabelecimento de periodizações, que, seguramente, não decorrem da adesão às hipóteses filosóficas do realismo ou idealismo, sendo enunciados com pretensão de verdade a serem demonstrados. Ou seja, o estabelecimento de uma cronologia diz respeito à crença realista que compartilhamos (ou não, dirão os idealistas) de que, em tal data, algo aconteceu: no dia 13 de dezembro de 1968 foi decretado o Al-5. Essa crença decorre de nossa adesão à hipótese filosófica do realismo segundo a qual - de modo grosseiramente simplificado - coisas aconteceram, existiram, e nós somos capazes de o saber. Outra coisa é a proposta gnosiológica de uma periodização, que pode ter motivação epistemológica convencionalista ou realista, mas será sempre hipótese a ser demonstrada, a não ser que se trate de simples opinião. Tratei dessas questões teóricas em outro trabalho que o leitor eventualmente interessado poderá consultar (FICO, 2012).

Seja como for, Daniel sustenta que a ditadura acabou com a revogação das leis de exceção por meio da Emenda Constitucional n. 11, de 13 de outubro de 1978, que extinguiu os atos institucionais a partir de $1^{\circ}$ de janeiro de 1979: "já não havia ditadura, mas ainda não existia uma democracia”. Em publicação de 2014, ele propôs que então teria surgido um estranho "Estado de direito autoritário" (REIS, 2014, p. 125). Em publicação anterior, Daniel havia falado em "Estado de direito precário" (REIS, 2000, p. 69). Sua periodização articula-se com a denominação que propõe para o regime: “o marco cronológico de 1985 estende um denso manto de silêncio sobre as bases sociais e políticas - civis - da ditadura" (REIS, 2014, p. 128). Ou seja, os que consideram que a ditadura só acabou com a eleição de um civil, seriam incapazes de perceber a importância do apoio dos civis - ainda que a razão para tal incapacidade não fique clara. A argumentação de Daniel associa-se a sua convicção de que haveria interesses inconfessáveis por trás da defesa de que a ditadura acabou em 1985, uma "estranha aliança" que teria legitimado o "silêncio sobre a participação civil no processo do golpe", uma "memória interessada", uma "ampla coligação de interesses e vontades", "verdadeira frente social, política e acadêmica" 
A propositura de periodização de dado processo histórico é atribuição nobre da História. As propostas não convencionalistas devem primar pela reunião de evidências empíricas que deem sustentação ao atributo. Os enunciados de Marco Antônio Villa e Daniel Aarão Reis não cumprem esse e outros requisitos e também são prejudicados pela forte conotação política que contêm. Na medida em que são fragilmente sustentados, parecem mera opinião e, como tal, desbordam com facilidade o ambiente acadêmico para sustentar a leitura política segundo a qual o regime que surgiu com o golpe de Estado de 1964 não foi muito prejudicial para o Brasil, já que a fase inicial e final nem teriam sido tão duras.

\section{5) Urgência e tradição}

O tempo dos militares alternava fases de turbulências "revolucionárias" entendidas como momentos de excepcionalidade, de aplicação de punições - e outras, de vivência ou de busca de relativa bonança institucional, que todos os governos militares pretenderam, exceto o do general Médici, que "aceitou a guerra", como vimos. Entendida desse modo, a temporalidade dos generais tanto guardava relação com a suposta urgência de saneamento do país - por meio das operações limpeza, das prisões, das punições - quanto com a alegada tradição democrática brasileira (daí a preocupação com a institucionalização).

Assim, a busca da normalidade institucional do regime supunha a incorporação na Constituição de mecanismos rigorosos de controle da sociedade que tornassem desnecessários os atos institucionais que, apesar do seu nome, não eram capazes de institucionalizar, ao contrário, eram excepcionais, eram "revolucionários", não permitindo a normalização do regime no sentido de sua juridicidade constitucional. Castelo Branco supôs que havia retornado à normalidade constitucional quando terminou

\footnotetext{
${ }^{43}$ Marco Antônio Villa também supõe que a ditadura acabou em 1979 (VILLA, 2014, p. 11 e 373 ).
} 
da Lei da Imprensa e da Lei de Segurança Nacional como medidas que funcionariam como salvaguardas para Costa e Silva, que assumiria desguarnecido de instrumentos excepcionais. Como vimos, esse aparato seria considerado inadequado em 1968.

A essas tentativas de institucionalização contrapunham-se os episódios nos quais o regime era levado a retornar às "fontes revolucionárias" do movimento de 1964, momentos que também eram chamados de "novo surto revolucionário" ou considerados como necessidade de "reativar a revolução" ou de "restaurar o princípio revolucionário". O retorno a essa matriz de excepcionalidade ocasionava, naturalmente, a imposição pela força de novo ato institucional que reabria a temporada de punições "revolucionárias", como havia se dado com o primeiro ato. Isso ocorreu claramente com o Al-2 e com o Al-5 em termos das punições mais importantes, mas as “origens revolucionárias” também foram acionadas com o Al-12, de $1^{\circ}$ de setembro de 1969, que foi, na verdade, um golpe de Estado contra o vice-presidente Pedro Aleixo, impedido de tomar posse quando o marechal Costa e Silva ficou doente, bem como, talvez em menor escala, com o $\mathrm{Al}-3$, que instituiu eleições indiretas para governadores, em 5 de fevereiro de 1966, e com o Al-6, que fez alterações no Supremo Tribunal Federal em $1^{\circ}$ de fevereiro de 1969. A instituição das penas de banimento e de morte, pelos atos 13 e 14, em 5 de setembro de 1969, motivadas pelo sequestro do embaixador norte-americano, agrediam a tradição jurídica brasileira e também são expressão da matriz "revolucionária” mencionada.

Nesse sentido, segundo o entendimento dos militares, desde 1964 o Brasil experimentou fases de excepcionalidade "revolucionária", com instrumentos que eles próprios consideravam autoritários e ditatoriais, combinadas com períodos durante os quais se viveu ou se buscou a institucionalização do regime. Entre 1964 e 1985, enquanto os generais estiveram no poder, sempre foi potencialmente possível reativar a revolução, porque os militares - como é óbvio - controlavam as armas. Por essa razão, pode-se designar o período como ditadura militar. Até a posse do primeiro presidente civil, o regime atribuía a si a prerrogativa de novo "surto revolucionário" que, na fase decadente 
temia soluções não constitucionais e morreu por causa disso. Na verdade, ainda que mitigada, a possibilidade de retrocesso esteve presente até o fim da ditadura militar, até a posse do primeiro presidente civil.

Quem mais se aproximou da importante temática do arcabouço institucional do regime foi Marcos Napolitano que, entretanto, afirmou que o governo Castelo Branco foi o "verdadeiro construtor institucional do regime autoritário. Nele foram editados quatro atos institucionais, a Lei de Imprensa e a nova Constituição, que selava o princípio de segurança nacional” (NAPOLITANO, 2016, p. 73). O problema dessa afirmação não está no erro factual, já que Castelo assinou apenas três atos institucionais, mas na suposição de que foi o primeiro presidente do regime militar o autor de sua moldura institucional.

Se entendermos por construção institucional ou moldura institucional o aparato normativo e legal que estabeleceu as estruturas que viabilizaram o Estado durante o regime militar, notadamente no que diz respeito à proeminência do Executivo sobre os demais poderes e sobre os cidadãos, nesse caso - divergindo de Napolitano - parece-me mais acertado sustentar que Costa e Silva tenha sido o responsável por tal moldura, que ele estabeleceu justamente no primeiro ato institucional, que assinou como chefe do Comando Supremo da Revolução, tendo um brigadeiro e um almirante como coadjuvantes. Por que afirmo isso?

Ora, como já sugeri, desde o golpe de 1964 e até 1985, o regime debateu-se com a questão de sua juridicidade a partir de uma dicotomia: a normalidade e a excepcionalidade. Esse problema está longe de ser exclusivo da ditadura brasileira, sendo, na verdade, secular, pois o regime brasileiro buscou equacionar tal dicotomia que tem origem na pretensão autoritária de corrigir a democracia por meio de atalhos constitucionais - com o emprego do estado de exceção. Como sugere Giorgio Agamben, é possível estabelecer analogias entre as versões contemporâneas do estado de exceção e a aplicação do iustitium romano enquanto "espaço vazio de direito (...) zona de anomia em que todas as determinações jurídicas (... ) estão desativadas": 
Esse espaço vazio de direito parece ser, sob alguns aspectos, tão essencial à ordem jurídica que esta deve buscar (...) assegurar uma relação com ele, como se, para se fundar, ela devesse manter-se (...) em relação com uma anomia (...) o vazio jurídico (...) se reveste, para a ordem jurídica, de uma relevância estratégica decisiva e que, de modo algum, se pode deixar escapar. (AGAMBEN, 2004, p. 78-79)

Portanto, a excepcionalidade pressupõe uma juridicidade. Desse modo, o objetivo dos atos institucionais não era "o reforço legal do Poder Executivo" nem a busca de “normatização autoritária” que garantiria previsibilidade ao sistema (NAPOLITANO, 2016, p. 79). O Ato Institucional imposto pela força das armas por Costa e Silva em 9 de abril de 1964 - contra outros delineamentos institucionais que, naquele momento, eram discutidos no Congresso Nacional - estabeleceu a moldura institucional dicotômica mencionada. Os atos seguintes e as constituições seguintes foram expressões das tentativas de prevalência da dimensão excepcional e da dimensão institucional. Não é outra a razão de a ditadura militar ter lidado com tantas constituições ou emendas constitucionais: a de 1946, alterada pelo Al-1; a de 1967, de Castelo Branco; a que Costa e Silva pediu a Pedro Aleixo para fazer com o propósito de apontar o fim do Al-5, em 1969; a que a Junta Militar outorgou em 1969, após a doença de Costa e Silva, justamente a que Pedro Aleixo havia coordenado, mas sem a referência à possibilidade de extinção do ato. Finalmente, as alterações estabelecidas pela Emenda Constitucional n. 11 de 1978, de Ernesto Geisel. Como se sabe, só o projeto de institucionalização de Ernesto Geisel teve sucesso.

Na reunião já mencionada do Conselho de Segurança Nacional, na qual o marechal Costa e Silva admitiu ter atuado como ditador no início do regime, ele disse que "a revolução não se fizera para oprimir o povo, pelo contrário, fora feita como uma contrarrevolução, justamente para evitar que esse povo fosse tiranizado (...) Se queríamos vencer uma tirania - disse o presidente - não poderíamos estabelecer outra tirania". Vale a pena transcrever trecho mais longo do marechal:

mas nós conseguimos, com a graça de Deus e compreensão dos homens, vencer aquela primeira etapa institucionalizando a revolução (...) O que desejávamos era o restabelecimento, no país, da garantia da ordem e da Constituição. Evidentemente, não se poderia atingir esses objetivos simplesmente pela mudança de homens, deveria haver, como houve, um 
ato para permitir que a revolução (...) gerasse os seus próprios direitos (... ) com a eliminação dos meios de perturbação (...) houve uma trégua e essa trégua, depois, foi tomada como um sentido de condescendência e tolerância (...) daí o ato número dois. Por incrível que pareça, o ato número dois não foi editado em virtude da atuação de cassados, decorreu da atitude de bons revolucionários, no primeiro momento (...) O que eu quero no entanto acentuar é que, desde o primeiro momento em que se fez a revolução, houve a preocupação que é a que ainda hoje caracteriza o processo revolucionário, a volta ao regime pleno democrático. ${ }^{44}$

Costa e Silva entendia estar à frente de governo plenamente constitucional, já que o Al-2 deixara de vigorar na véspera de sua posse. Quando o ministro da Marinha apoiou sua tese de que as manifestações de 1968 podiam ser combatidas sem instrumentos excepcionais, o marechal acolheu a fala com visível satisfação e disse que podiam contar com o "livrinho", como dizia Dutra. ${ }^{45}$ Quando a reunião acabou e se discutiu a elaboração de uma nota para a imprensa, Costa e Silva determinou que não se falasse em atos institucionais nem mesmo como ameaça, porque, "se a tanto for levado, será com grande sacrifício e com grande pesar de um velho revolucionário, pois será um retrocesso no processo que se vem desenrolando". ${ }^{46}$

$\mathrm{O}$ ato acabaria vindo cinco meses depois, de modo que o marechal, tido como um sargentão pelos que o ironizam, foi o responsável pelos dois principais delineamentos excepcionais do regime (o Al-1 e o Al-5). Entretanto, Costa e Silva não desistiu do processo de institucionalização. Determinou que o vice-presidente, Pedro Aleixo, fizesse nova constituição para permitir o fim paulatino dos atos institucionais. Pedro Aleixo entregou trezentas laudas no dia 24 de junho de 1969. Costa e Silva as leu e anotou até o início de julho. Depois, entre 14 e 17 de julho de 1969, o marechal coordenou pessoalmente os trabalhos de comissão que convocou para discutir o projeto. Participaram seus ministros Rondon Pacheco (Gabinete Civil) e Helio Beltrão (Planejamento), o ministro do STF Temístocles Cavalcanti, o ex-ministro do STF Carlos Medeiros e o reitor da USP, Miguel Reale. Terminados os trabalhos, o projeto

\footnotetext{
${ }^{44}$ Arquivo Nacional. Ata da continuação da $41^{\text {a }}$ sessão, de 11 de julho de 1968, do Conselho de Segurança Nacional, em 16 de julho de 1968. Livro 4, fl. 30.

${ }^{45}$ Arquivo Nacional. Ata da 41 ${ }^{\text {a }}$ Sessão do Conselho de Segurança Nacional, de 11 de julho de 1968. Livro 4, fl. 15.

${ }^{46}$ Arquivo Nacional. Ata da continuação da $41^{\text {a }}$ sessão, de 11 de julho de 1968 , do Conselho de Segurança Nacional, em 16 de julho de 1968. Livro 4, fl. 33.
} 
demais atos posteriormente baixados" (ALEIXO, 2002). O projeto também se fundamentava em uma salvaguarda: a ampliação dos poderes do presidente da República para decretar o Estado de Sítio, que então poderia ser por 180 dias (a Constituição de 1967 de Castelo havia aumentado os trinta dias previstos na Constituição de 1946 para sessenta).

Costa e Silva planejou reabrir o Congresso Nacional (fechado desde o Al-5) e promulgar a emenda constitucional no dia $1^{\circ}$ de setembro de 1969 . Os ministros militares não apoiavam nem uma coisa, nem outra, mas não podiam se contrapor ao chefe do movimento de 1964 que havia assinado o Ato Institucional e o Al-5. Três dias antes da data marcada, o marechal teve uma trombose que o afastaria definitivamente do cargo. Na sequência, seus ministros militares deram um golpe de Estado, impedindo o vicepresidente Pedro Aleixo de assumir a Presidência da República, modificaram o projeto em pontos essenciais e promulgaram a Constituição com alterações. A nova redação do artigo 182 passou a ser: "continuam em vigor o Ato Institucional n. 5, de 13 de dezembro de 1968, e os demais atos posteriormente baixados." Esses detalhes são ignorados ou obscurecidos pela literatura especializada. Prevalece a narrativa simplificada sobre o perfil de Costa e Silva como líder da chamada linha dura e responsável pelo Al-5 - que teria sido, segundo o chavão irônico e paradoxal, o "golpe dentro do golpe", quando, na verdade, O Al-5 foi apenas mais uma manifestação da dinâmica que havia entre as tendências de institucionalização e de excepcionalidade: não houve mudança de natureza do regime com o Al-5. Novo golpe, depois do ocorrido em 1964, houve, de fato, em 1969, contra Pedro Aleixo.

Muitos anos depois, Ernesto Geisel enfrentaria problemas parecidos, inclusive causados por "bons revolucionários", que no seu caso eram os "revolucionários sinceros, mas radicais", 47 expressão que usou no discurso que fez diante dos dirigentes da Arena, no dia $1^{\circ}$ de dezembro de 1977 , no Palácio da Alvorada. Foi nesse discurso que Geisel

\footnotetext{
47 O comentarista político Carlos Castello Branco registrou "bolsões revolucionários". Geisel não usou a expressão "bolsões". Ver a coluna de Castello Branco no Jornal do Brasil de 24 de fevereiro de 1978.
} 
PRESIDÊNCIA DA REPÚBLICA, 1996, p. 340-341). Tais salvaguardas eram o Estado de Emergência e as Medidas de Emergência, incluídos na Emenda Constitucional n. 11, de 13 de outubro de 1978, que extinguiu os atos de exceção. O Estado de Emergência permitia a aplicação de todas as medidas do Estado de Sítio pelo presidente da República, sem a necessidade de autorização do Congresso Nacional, sempre que os poderes ou as instituições estivessem "gravemente ameaçados ou atingidos por fatores de subversão". Segundo o jurista Enrique Ricardo Lewandowski,

Na hipótese de decretação ou de prorrogação do Estado de Emergência, a decisão presidencial é meramente comunicada ao Congresso, cinco dias depois de tomada pelo chefe de governo. O Legislativo, nesse caso, passa a ser um mero expectador da aplicação de um dos mais violentos remédios para preservação das instituições existentes em todo o ordenamento constitucional (...) o presidente tem a mais ampla autonomia para decretar o Estado de Emergência, posto que não se encontra tolhido de qualquer modo pelos demais poderes da República (...) A consulta ao Conselho Constitucional é meramente formal. (LEWANDOWSKI, 1984, p. 158)

Essas salvaguardas vigorariam até a Constituição de 1988. As medidas de emergência foram utilizadas na região de Brasília em outubro de 1983 (por ocasião de votação de decretos sobre política salarial) e em abril de 1984, para pressionar o Congresso Nacional a rejeitar a emenda das diretas. Na ocasião, o presidente João Figueiredo disse que, se a emenda fosse aprovada, corria-se o risco de haver um golpe, informação dada ao deputado governista Francisco Salles que teve um encontro com o general. ${ }^{48} \mathrm{~A}$ possibilidade de uso do Estado de Emergência e das Medidas de Emergência torna a proposta de periodização de Daniel Aarão Reis Filho e de Marco Antonio Villa, para o final da ditadura, ainda mais discutível.

Foram esses antecedentes relacionados à moldura institucional do regime que inspiraram Ernesto Geisel a delinear o projeto de “lenta, gradativa e segura distensão".

\footnotetext{
${ }^{48}$ Jornal do Brasil. Rio de Janeiro, 19 de janeiro de 1984. p. 1.
} 

assentar seu projeto", bem como havia resistências, caso "não fossem dadas garantias suficientes aos setores comprometidos com a ditadura e a repressão política de que estes não seriam julgados" (MATHIAS, 1995, p. 62, 65 e 68). Havia, sobretudo, as tentativas de institucionalização, desde o governo do marechal Castelo Branco, feitas com base na constitucionalização, por meio de salvaguardas que implicavam tornar mais rigoroso o Estado de Sítio e instrumentos assemelhados. Tais salvaguardas sempre foram pensadas como substituição dos mecanismos de controle da sociedade previstos nos atos institucionais excepcionais. Foi exatamente isso que Geisel fez. A diferença é que, ao contrário de Castelo Branco e de Costa e Silva, ele foi bem-sucedido. Médici simplesmente não tentou, embora tenha estabelecido transmitir o governo a um civil, caso a "luta armada" estivesse inteiramente derrotada. Segundo seu filho, ele optaria por um general da ativa se o confronto fosse grave e, por um general da reserva, "se as coisas estiverem a meio caminho" - alternativa em que se fixou (MÉDICI, 1995, p. 31). Geisel foi o escolhido e, portanto, seu projeto de distensão não foi resultado de seu perfil psicológico, como sugere a obra de Gaspari, mas decorreu do acúmulo histórico dessas experiências.

Muitos analistas sustentam que o projeto inicial de Geisel foi modificado pela pressão da sociedade. ${ }^{49}$ Suzeley Kalil Mathias, que defende, como eu, a existência do projeto de Geisel, julga, entretanto, que a anistia e a reforma partidária decorreram da necessidade que o governo teve de "negociar reformas e ampliar limites" (MATHIAS, 1995, p. 143). Entretanto, a dissolução dos partidos vinha sendo discutida por Geisel e Golbery desde pelo menos 1975, tanto quanto o fim do Al-5 e a anistia (GASPARI, 2004, p. 89-91). Ou seja, o projeto de Geisel estava delineado desde o início de seu governo e previa todas essas etapas, sendo as mais importantes a autoanistia, o enfraquecimento do MDB com o fim do bipartidarismo e a escolha de novo presidente militar por via indireta. Assim, apesar da campanha, a anistia não foi "ampla, geral e irrestrita" e

\footnotetext{
${ }^{49}$ Ver, por exemplo, Araujo (2004, p. 162).
} 
perdoou os torturadores. Novos partidos foram criados. A Campanha das Diretas não impediu que o Colégio Eleitoral atuasse mais uma vez. Se a resistência democrática não conseguiu acelerar a abertura, ela foi desimportante? São coisas diferentes: a dinâmica social daquela época foi muito importante para a configuração da democracia como a temos hoje em nosso país. A Constituição de 1988 foi marcada pelas demandas que mobilizaram as manifestações sociais do final da ditadura. Mas a saída do regime militar foi controlada pelos militares. Francisco Carlos Teixeira da Silva chamou atenção para o fato de Geisel ter garantido que "não havia projeto algum”. Curiosamente, na sequência dessa declaração, o ex-presidente descreveu os princípios gerais da distensão e apontou a linha dura como ator junto com a oposição - ou seja, descreveu seu projeto (SILVA, 2003, p. 264).

Foi também Francisco Carlos quem distinguiu aspecto importante: no final do processo, a insistência de Paulo Maluf em candidatar-se à Presidência da República "poderia, perigosamente, romper a frágil arquitetura inicial de Golbery/Geisel e do primeiro Figueiredo, lançando o país em agruras econômicas e financeiras, numa transição por colapso." Francisco Carlos, nessa passagem, está se referindo ao imobilismo do general Figueiredo na fase final de seu governo, que o impediu de coordenar sua sucessão, e à ofensiva de Paulo Maluf para tornar-se candidato pelo partido que apoiava o regime, ainda que, para tanto, fosse preciso pôr em risco o próprio esquema de sustentação do regime. Os partidos políticos, então, tomaram a frente do processo "para evitar retrocesso ou rupturas" e, de fato, concertaram a derrota de Maluf e a saída da ditadura. Francisco Carlos afirma que essa "não era mais a abertura de Geisel e Golbery". A mim parece que estava sendo garantida a abertura de Geisel e Golbery apesar da falta de liderança do último Figueiredo e da turbulência causada por Maluf (SILVA, 2003, p. 273275. Grifado no original). Ou seja, a Aliança Democrática e a Nova República foram o coroamento da distensão lenta, gradativa e segura.

Não creio ser necessário retomar, em conclusão, tudo o que já foi dito. Apenas reafirmo, por fim, minha convicção de que o debate teórico-conceitual e historiográfico dessas questões tão importantes só é possível em função da alta qualidade atingida pela produção dos autores aqui mencionados. 


\section{Referências}

AGAMBEN, Giorgio. Estado de exceção. Tradução de Iraci D. Poleti. São Paulo: Boitempo, 2004.

ALEIXO, José Carlos Brandi. Pedro Aleixo, organizador e relator da reforma constitucional. In: SENADO FEDERAL. A constituição que não foi: história da Emenda Constitucional n. 1, de 1969. Brasília; Senado Federal, 2002.

ALMEIDA, Guilherme Bacha de. O Conselho de Segurança Nacional e a ditadura (19641969). In: MOTTA, Rodrigo Patto Sá (Org.). Ditaduras militares: Brasil, Argentina, Chile e Uruguai. Belo Horizonte: UFMG, 2015.

ARAUJO, Maria Paula. A luta democrática contra o regime militar na década de 1970. In: REIS, Daniel Aarão; RIDENTI, Marcelo; MOTTA, Rodrigo Patto Sá (Orgs.). 0 golpe e a ditadura militar: 40 anos depois (1964-2004). Bauru: Edusc, 2004.

BERSTEIN, Serge. Culturas políticas e historiografia. In: AZEVEDO, Cecília e outros. Cultura política, memória e historiografia. Rio de Janeiro: FGV, 2009.

BRASIL. PRESIDÊNCIA DA REPÚBLICA. Governos da República: 15.11.1889 a 15.03.1996. Presidência da República, Casa Civil, Biblioteca. $3^{\text {a }}$ ed. rev. e atual. Brasília, 1996.

CARDOSO, Ciro Flamarion Santana. Epistemologia pós-moderna, texto e conhecimento: a visão de um historiador. Diálogos. Maringá, v. 3, n. 3, p. 1-28, 1999.

CHARTIER, Roger. Le monde comme représentation. Annales E.S.C. Paris, nov./dec./ 1989 n. 6 p. $1505-1520$.

CARDOSO, Fernando Henrique. O modelo político brasileiro e outros ensaios. São Paulo: Difel, 1972.

CHAUÍ, Marilena. Apontamentos para uma crítica da Ação Integralista Brasileira. In: CHAUÍ, Marilena; FRANCO, Maria Sylvia de Carvalho. Ideologia e mobilização popular. Rio de Janeiro: Paz e Terra, 1978.

CODATO, Adriano Nervo. O golpe de 1964 e o regime de 1968: aspectos conjunturais e variáveis históricas. História: Questões \& Debates. Curitiba, n. 40, p. 11-36, 2004.

D'ARAUJO, Maria Celina. Sindicatos, carisma e poder: o PTB de 1945-65. Rio de Janeiro: FGV, 1996.

DANIEL, Herbert. Passagem para o próximo sonho. Rio de Janeiro: Codecri, 1982. 
DIAS, Luiz Antonio. Entre letras e números: uma análise do jornal Folha de S. Paulo e de pesquisas de opinião do Ibope (1963-1964). In: FERNANDES, Carla M.; CHAGAS, Genira. (Orgs.). Mídia e governos autoritários: 60 anos do suicídio de Getúlio Vargas e 50 anos do golpe civil-militar no Brasil. João Pessoa: Idea, 2014.

FERREIRA, Jorge. O governo Goulart e o golpe civil-militar de 1964. In: FERREIRA, Jorge; DELGADO, Lucília de Almeida Neves (Orgs.). O Brasil republicano: o tempo da experiência democrática - da democratização de 1945 ao golpe civil-militar de 1964 (Livro 3). Rio de Janeiro: Civilização Brasileira, 2003.

FERREIRA, Jorge. Entre o comício e a mensagem: o presidente Goulart, as esquerdas e a crise política de março de 1964. In: AZEVEDO, Cecília e outros. Cultura política, memória e historiografia. Rio de Janeiro: FGV, 2009.

FICO, Carlos. Reinventando o otimismo: ditadura, propaganda e imaginário social no Brasil. Rio de Janeiro: FGV, 1997.

FICO, Carlos. Como eles agiam. Os subterrâneos da ditadura militar: espionagem e polícia política. Rio de Janeiro: Record, 2001.

FICO, Carlos. Espionagem, polícia política, censura e propaganda: os pilares básicos da repressão. In Ferreira, Jorge, Neves, Lucilia de Almeida (Orgs.). O Brasil republicano. Livro 4: O tempo da ditadura - regime militar e movimentos sociais em fins do século XX. Rio de Janeiro: Record, 2003.

FICO, Carlos. Além do golpe: versões e controvérsias sobre 1964 e a ditadura militar. Rio de Janeiro: Record, 2004.

FICO, Carlos. $O$ grande irmão. Da Operação Brother Sam aos anos de chumbo: o governo dos Estados Unidos e a ditadura militar brasileira. Rio de Janeiro: Civilização Brasileira, 2008.

FICO, Carlos. A ditadura documentada. Acervo. Rio de Janeiro, v. 21, n. 2, p. 67-78, jul./dez. 2008a.

FICO, Carlos. 1968: o ano que terminou mal. In: FICO, Carlos; ARAÚJO, Maria Paula (Orgs.). 1968, 40 anos depois: história e memória. Rio de Janeiro: 7Letras, 2009.

FICO, Carlos. Les régimes autoritaires au Brésil durant l'ére républicaine. Brésil(s). Sciences humaines et sociales. Paris, v. 1, Ouverture, p. 30-40, 2011.

FICO, Carlos. História que temos vivido. In: VARELLA, Flávia e outros (Orgs.). Tempo presente \& usos do passado. Rio de Janeiro: FGV, 2012. 
FICO, Carlos. Violência, trauma e frustração no Brasil e na Argentina: o papel do historiador. Topoi. Revista de História. Rio de Janeiro, v. 14, n. 27, p. 239-284, jul./dez. 2013.

FICO, Carlos. História do Brasil contemporâneo: da morte de Vargas aos dias atuais. São Paulo: Contexto, 2015.

FIGUEIREDO, Argelina Cheibub. Democracia ou Reformas? Alternativas democráticas à crise política: 1961-1964. Tradução de Carlos Roberto Aguiar. Rio de Janeiro: Paz e Terra, 1993.

FONTES, Virgínia. Nas lutas. In: MELO, Demian Bezerra de (Org.) A miséria da historiografia: uma crítica ao revisionismo contemporâneo. Rio de Janeiro: Consequência, 2014.

GARCIA, Miliandre. "Ou vocês mudam ou acabam": teatro e censura na ditadura militar (1964-1985). Tese de doutorado apresentada ao Programa de Pós-graduação em História Social da UFRJ. Rio de Janeiro, 2008.

GASPARI, Elio. A ditadura encurralada. São Paulo: Companhia das Letras, 2004.

GORENDER, Jacob. Combate nas trevas. A esquerda brasileira: das ilusões perdidas à luta armada. 2. ed. São Paulo: Ática, 1987.

GORENDER, Jacob. A escravidão reabilitada. LPH - Revista de História. Mariana, v. 3, n. 1, p. 245-266, 1992.

HEMPEL, Carl G. The Function of General Laws in History. The Journal of Philosophy. New York, v. 39, n. 2, p. 35-48, Jan. 1942.

HOBSBAWM, Eric. Não basta a história da identidade. In: Sobre história: ensaios. Tradução de Cid Knipel Moreira. São Paulo: Companhia das Letras, 1998.

LACAPRA, Dominick. Writing History, Writing Trauma. Baltimore: The Johns Hopkins University Press, 2001.

LARA, Silvia Hunold. Escravidão no Brasil: balanço historiográfico. LPH - Revista de História. Mariana, v. 3, n. 1, p. 215-244, 1992.

LEWANDOWSKI, Enrique Ricardo. As salvaguardas do Estado no Brasil. Revista da Faculdade de Direito. São Paulo, v. 79, p. 140-160, jan. 1984. 
MARTINS FILHO, João Roberto. Movimento estudantil e ditadura militar: 1964-1968. Campinas: Papirus, 1987.

MARTINS, Franklin. Prefácio. In: GURGEL, Antonio de Padua. A rebelião dos estudantes: Brasília, 1968. Brasília: UnB, 2002.

MARTINS, William de Souza Nunes. Produzindo no escuro: políticas para a indústria cinematográfica brasileira e o papel da censura (1964-1988). 2009. Tese (doutorado em História Social ) - UFRJ, Programa de Pós-graduação em História Social, Rio de Janeiro, 2009.

MATHIAS, Suzeley Kalil. Distensão no Brasil: o projeto militar (1973-1979). Campinas: Papirus, 1995.

MATTOS, Marcelo Badaró. O governo João Goulart: novos rumos da produção historiográfica. Revista Brasileira de História. São Paulo, v. 28, n. 55, p. 245-263, 2008.

MATTOS, Marcelo Badaró. As bases teóricas do revisionismo: o culturalismo e a historiografia brasileira contemporânea. In: MELO, Demian Bezerra de (Org.) A miséria da historiografia: uma crítica ao revisionismo contemporâneo. Rio de Janeiro: Consequência, 2014.

MÉDICl, Roberto Nogueira. Médici, o depoimento. Rio de Janeiro: Mauad. 1995.

MELO, Demian Bezerra de (Org.) A miséria da historiografia: uma crítica ao revisionismo contemporâneo. Rio de Janeiro: Consequência, 2014.

MELO, Demian Bezerra de. A miséria da historiografia. Outubro. n. 14, p. 111-130, $2^{\circ}$. sem. 2006.

MELO, Demian Bezerra de. O golpe de 1964 e meio século de controvérsias: o estado atual da questão. In: MELO, Demian Bezerra de (Org.) A miséria da historiografia: uma crítica ao revisionismo contemporâneo. Rio de Janeiro: Consequência, 2014.

MOORE JR. Barrington. As origens sociais da ditadura e da democracia. Tradução de Maria Ludovina F. Couto. São Paulo: Martins Fontes, 1983.

MOTTA, Rodrigo Patto Sá. As universidades e o regime militar: cultura política brasileira e modernização autoritária. Rio de Janeiro: Zahar, 2014.

NAGEL, Ernest. Some issues in the Logic of the Historical Analysis. The Scientific Monthly. New York, v. 74, n. 3, p. 162-169, March, 1952. 
NAPOLITANO, Marcos. A "resistência cultural” durante o regime militar brasileiro: um novo olhar historiográfico. In: MOTTA, Rodrigo Patto Sá (Org.). Ditaduras militares: Brasil, Argentina, Chile e Uruguai. Belo Horizonte: UFMG, 2015.

NAPOLITANO, Marcos. 1964: história do regime militar brasileiro. São Paulo: Contexto. 2016.

OLIVEIRA, Eliézer Rizzo de. As Forças Armadas: política e ideologia no Brasil (1964-1969). Petrópolis: Vozes, 1976.

OLIVEIRA, Gil Vicente Vaz. Fotojornalismo subversivo: 1968 revisto pelas lentes do Correio da Manhã. Acervo, Rio de Janeiro, v. 11, nº 1-2, p. 117-136, jan./dez., 1998.

PALMEIRA, Vladimir. Vladimir Palmeira [entrevista concedida por]. In: REIS FILHO, Daniel Aarão; MORAES, Pedro de. 1968: a paixão de uma utopia. 3. ed. Rio de Janeiro: FGV, 2008.

REIS, Daniel Aarão. Ditadura militar, esquerdas e sociedade. Rio de Janeiro: Jorge Zahar, 2000.

REIS, Daniel Aarão. Ditadura e sociedade: as reconstruções da memória. In: REIS, Daniel Aarão; RIDENTI, Marcelo; MOTTA, Rodrigo Patto Sá (Orgs.). O golpe e a ditadura militar: 40 anos depois (1964-2004). Bauru: Edusc, 2004.

REIS, Daniel Aarão. Trinta anos depois. In: REIS FILHO, Daniel Aarão; MORAES, Pedro de. 1968: a paixão de uma utopia. 3. ed. Rio de Janeiro: FGV, 2008.

REIS, Daniel Aarão. Ditadura, anistia e reconciliação. Estudos Históricos. Rio de Janeiro, v. 23, n. 45, p. 171-186, jan./jun. 2010.

REIS, Daniel Aarão. Ditadura e democracia no Brasil: do golpe de 1964 à Constituição de 1988. Rio de Janeiro: Zahar, 2014

REIS, Daniel Aarão; ROLLAND, Denis. Apresentação. In: REIS, Daniel Aarão; ROLLAND, Denis (Orgs.). Modernidades alternativas. Rio de Janeiro: FGV, 2008.

REIS FILHO, Daniel Aarão. A revolução faltou ao encontro: os comunistas no Brasil. São Paulo: Brasiliense, 1980.

REIS FILHO, Daniel Aarão e outros. Versões e ficções: o sequestro da história. São Paulo: Perseu Abramo, 1997. 
REIS FILHO, Daniel Aarão. 1968, o curto ano de todos os desejos. Tempo Social. São Paulo, v. 10, n. 2, p. 25-35, out. 1998.

REIS FILHO, Daniel Aarão. Ditadura no Brasil: entre memória e história. In: MOTTA, Rodrigo Patto Sá (Org.). Ditaduras militares: Brasil, Argentina, Chile e Uruguai. Belo Horizonte: UFMG, 2015.

REIS FILHO, Daniel Aarão; MORAES, Pedro de. 1968: a paixão de uma utopia. 3. ed. Rio de Janeiro: FGV, 2008.

RIDENTI, Marcelo. O fantasma da revolução brasileira. São Paulo: UNESP, 1993.

RIDENTI, Marcelo. Que história é essa? In: REIS FILHO, Daniel Aarão e outros. Versões e ficções: o sequestro da história. São Paulo: Perseu Abramo, 1997.

RIDENTI, Marcelo. Cultura e política: os anos 1960-1970 e sua herança. In: FERREIRA, Jorge; DELGADO, Lucília de Almeida Neves (Orgs.). O Brasil republicano: o tempo da ditadura - regime militar e movimentos sociais em fins do século XX (Livro 4). Rio de Janeiro: Civilização Brasileira, 2003.

RIDENTI, Marcelo. Canetas e fuzis: intelectuais e artistas brasileiros nos anos 1960/70. In: REIS, Daniel Aarão; ROLLAND, Denis (Orgs.). Modernidades alternativas. Rio de Janeiro: FGV, 2008.

ROLLEMBERG, Denise. $O$ apoio de Cuba à luta armada no Brasil: o treinamento guerrilheiro. Rio de janeiro: Mauad, 2001.

ROLLEMBERG, Denise. Esquerdas revolucionárias e luta armada. In: FERREIRA, Jorge; DELGADO, Lucília de Almeida Neves (Orgs.). O Brasil republicano: o tempo da ditadura regime militar e movimentos sociais em fins do século XX (Livro 4). Rio de Janeiro: Civilização Brasileira, 2003.

ROLLEMBERG, Denise. Memória, opinião e cultura política. A Ordem dos Advogados do Brasil sob a ditadura (1964-1974). In: REIS, Daniel Aarão; ROLLAND, Denis. (Orgs.).

Modernidades alternativas. Rio de Janeiro: Editora da Fundação Getúlio Vargas, 2008, p. 57-96.

ROLLEMBERG, Denise. As trincheiras da memória. A Associação Brasileira de Imprensa e a ditadura (1964-1974). In: ROLLEMBERG, Denise; QUADRAT, Samantha Viz. (Orgs.). A construção social dos regimes autoritários. Legitimidade, consenso e consentimento no Século XX: Brasil e América Latina. Rio de Janeiro: Civilização Brasileira, 2010, vol. 2, p. 97144. 
ROLLEMBERG, Denise; QUADRAT, Samantha Viz. (Orgs.). A construção social dos regimes autoritários. Legitimidade, consenso e consentimento no Século XX: Brasil e América Latina. Rio de Janeiro: Civilização Brasileira, 2010, vol. 2.

SAES, Décio. Classe média e política no Brasil (1930-1964). In: FAUSTO, Boris (Dir.). História geral da civilização brasileira. Tomo III: O Brasil republicano, $3^{\circ}$ volume: Sociedade e política (1930-1964). São Paulo: Difel, 1981.

SCARTEZINI, Antonio Carlos. Segredos de Medici. São Paulo: Marco Zero, 1985.

SCHMITTER, Philippe C. Interest conflict and political change in Brazil. California: Stanford University Press, 1971.

SCHNEIDER, Ronald M. The political system of Brazil: emergence of a "modernizing" authoritarian regime, 1964-1970. New York: Columbia University Press, 1971.

SERRA, Jose'. Cinquenta anos esta noite: o golpe, a ditadura e o exílio. Rio de Janeiro: Record, 2014.

SILVA, Francisco Carlos Teixeira da. Crise da ditadura militar e o processo de abertura política no Brasil, 1974-1985. In: FERREIRA, Jorge; DELGADO, Lucília de Almeida Neves (Orgs.). O Brasil republicano: o tempo da ditadura - regime militar e movimentos sociais em fins do século XX (Livro 4). Rio de Janeiro: Civilização Brasileira, 2003.

SILVA, Izabel Priscila Pimentel da. Os filhos rebeldes de um velho camarada: a dissidência comunista da Guanabara (1964-1969). 2009. Dissertação (Mestrado em História) - UFF, Programa de Pós-graduação em História, Niterói, 2009.

SIRKIS, Alfredo. Os carbonários. Rio de Janeiro: Record, 1998.

SOUZA, Jessé. A tolice da inteligência brasileira. São Paulo: LeYa, 2015.

STACCHINI, José. Março 64: mobilização da audácia. São Paulo: Companhia Editora Nacional, 1965.

STEPAN, Alfred. The military in politics: changing patterns in Brazil. Princeton University Press, 1971.

TOLEDO, Caio N. de. 1964: golpismo e democracia. As falácias do revisionismo. Crítica Marxista. Campinas, n. 19, p. 27-48, 2004. 
VILLA, Marco Antonio. Jango: um perfil (1945-1964). São Paulo: Globo, 2004.

VILLA, Marco Antonio. Ditadura à brasileira - 1964-1985: a democracia golpeada à esquerda e à direita. São Paulo: LeYa, 2014.

Recebido em 17/03/2017 Aprovado em 28/04/2017

Universidade do Estado de Santa Catarina - UDESC

Programa de Pós-Graduação em História - PPGH

Revista Tempo e Argumento Volume 09 - Número 20 - Ano 2017 tempoeargumento@gmail.com 